\title{
НАВЧАЛЬНО-МЕТОДИЧНЕ ЗАБЕЗПЕЧЕННЯ НАВЧАЛЬНОГО ПРОЦЕСУ - ОБОВ'ЯЗКОВА ВИМОГА ПРОВАДЖЕННЯ ОСВІТНЬОЇ ДІЯЛЬНОСТІ У ЗАКЛАДАХ ВИЩОЇ ОСВІТИ
}

\author{
I. V. Melnyk, M. O. Polishchuk, T. I. Farion \\ Central Methodical Cabinet for Higher Medical Education of the Ministry of Health of Ukraine
LEARNING AND TEACHING SUPPORT MATERIALS OF THE EDUCATIONAL PROCESS IS AN EXCLUSIVE REQUIREMENT FOR CONDUCTING LEARNING ACTIVITIES IN HIGHER EDUCATIONAL INSTITUTIONS

\begin{abstract}
Мета роботи - провести аналіз інформації щодо забезпечення закладів вищої освіти Міністерства охорони здоров’я України навчально-методичними матеріалами з дисциплін “Іноземна мова” та “Іноземна мова (за професійним спрямуванням)” для належної організації підготовки студентів до складання іспиту з англійської мови за професійним спрямуванням як окремої компоненти ЄДКІ.

Основна частина. Удосконалення якості підготовки лікарів як обов'язкової складової реалізації реформи охорони здоров’я в Україні потребує послідовної роботи з покращення додипломної підготовки здобувачів ступеня вищої освіти “Магістр” за усіма спеціальностями галузі знань “Охорона здоров’я”. Натепер ще не завершена робота з розробки та затвердження стандартів вищої освіти для кожного рівня вищої освіти в межах кожної спеціальності з урахуванням пропозицій галузевих державних органів, до сфери управління яких належать вищі навчальні заклади, та галузевих об’єднань організацій роботодавців на виконання статті 10 Закону України “Про вищу освіту”.

Висновок. Для удосконалення організації підготовки студентів до складання іспиту з англійської мови за професійним спрямуванням як окремої компоненти ЄДКІ необхідно розробити низку заходів для забезпечення формування у студентів закладів вищої освіти МОЗ України, які не вивчають англійську мову як іноземну чи іноземну мову за професійним спрямуванням, компетентностей, необхідних для складання іспиту з англійської мови за професійним спрямуванням як окремої компоненти ЄДКІ, у тому числі шляхом вивчення курсів за вибором “Іноземна мова (друга): англійська” та “Іноземна мова за професійним спрямуванням (друга): англійська”, вжити заходів для збільшення кількості навчально-методичної літератури, виданої англійською мовою, та покращити матеріально-технічне оснащення кафедр іноземних мов.
\end{abstract}

Ключові слова: навчальний процес; заклади вищої освіти; навчально-методичне забезпечення.

The aim of the work - to conduct an information analysis on the provision of higher education institutions of the Ministry of Health of Ukraine with the teaching materials on the disciplines "Foreign language" and "Foreign language (professionally oriented)" for the proper organization of students' preparation for the professionally oriented English language examination as a separate component of the OCSE (The One Comprehensive State Exam).

The main body. Improving the quality of doctors' training as an obligate part of implementing the health care reform in Ukraine requires consistent work in improving the pre-graduate training of graduates in Master degree in all specialties of the field of knowledge "Healthcare". At the present time, the work on the development and approval of higher education standards for each level of higher education within each specialty has not yet been completed, taking into account the proposals of the industrial government bodies to which the higher education institutions belong, as well as industrial groups of employers' organizations in pursuance of Article 10 Law of Ukraine "On Higher Education”.

Conclusions. To improve the organization of preparing students for the professionally oriented English language examination as a separate component of the OCSE, it is necessary to develop a series of measures to ensure the formation of students (who study in higher education establishments of the Ministry of Health of Ukraine, but do not study English as a foreign or foreign language according to the professional orientation), competencies required for the professionally oriented English language examination as a separate component of the OCSE, including optional courses studying “Foreign Language (Second): English” and "Professionally Oriented Foreign Language: English”, take measures to increase the number of teaching materials in English, and improve the material and technical equipment of the foreign language departments.

Key words: educational process; higher education establishments; teaching materials.

(c) I. В. Мельник, М. О. Поліщук, Т. І. Фаріон 
Вступ. Удосконалення якості підготовки лікарів як обов’язкової складової реалізації реформи охорони здоров’я в Україні потребує послідовної роботи з покращення додипломної підготовки здобувачів ступеня вищої освіти “Магістр” за усіма спеціальностями галузі знань “Охорона здоров'я”.

У статті 75 Закону України “Основи законодавства України про охорону здоров’я” зазначено, що “навчальні плани та програми підготовки, перепідготовки та підвищення кваліфікації медичних і фармацевтичних працівників у встановленому порядку погоджуються з центральним органом виконавчої влади, що забезпечує формування державної політики у сфері охорони здоров'я” [1].

Відповідно до Закону України “Про вищу освіту” [2], діяльність закладів вищої освіти і наукових установ, що провадиться з метою підготовки здобувачів вищої освіти на певних її рівнях за певними спеціальностями, здійснюється відповідно до вимог щодо провадження освітньої діяльності у сфері вищої освіти, визначених у Ліцензійних умовах провадження освітньої діяльності закладів освіти (Постанова Кабінету Міністрів України від 30.12.2015 року № 1187, далі - Ліцензійні умови) [3].

Міністерство освіти і науки України підготувало до затвердження нові Ліцензійні умови, в яких будуть скасовані завищені вимоги до обсягу навчально-методичних комплексів дисциплін. Разом з тим $€$ базові речі, і в нових Ліцензійних умовах навчально-методичне забезпечення передбачає наявність усіх затверджених освітніх програм, навчальних планів, робочих програм, програм практичної підготовки тощо (анонсовано заступником міністра освіти і науки Юрієм Рашкевичем 23.02.2018 року).

Окрім дотримання закладом вищої освіти Ліцензійних умов, одним 3 основних критеріїв якості надання освітніх послуг у галузі знань “Охорона здоров'я” $є$ неупереджена, фахова та стандартизована оцінка якості підготовки випускників.

3 урахуванням статті 6 Закону України "Про вищу освіту”, якою визначена можливість здійснення атестації здобувачів ступеня магістра у формі єдиного державного кваліфікаційного іспиту (далі - ЄДКІ) за спеціальностями та у порядку, визначеними Кабінетом Міністрів України, Урядом прийнято Постанову від 28.03.2018 року “Про затвердження Порядку здійснення єдиного державного кваліфікаційного іспиту для здобувачів ступеня вищої освіти “Магістр” за спеціальностями галузі знань 22 “Охорона здоров’я” (далі - Постанова від
28.03.2018 року), в якій установлено, що атестація здобувачів ступеня вищої освіти “Магістр” за спеціальностями галузі знань 22 “Охорона здоров’я” буде включати як окремий компонент ЄДКІ іспит 3 англійської мови за професійним спрямуванням.

При цьому, згідно з пунктом 13 Постанови від 28.03.2018 року, “при неуспішному складанні будь-якого з компонентів ЄДКІ, здобувач має право повторно скласти іспит не більше одного разу. Повторне складання іспиту допускається протягом одного року з дня проведення першого іспиту”.

Мета роботи - провести аналіз інформації щодо забезпечення закладів вищої освіти Міністерства охорони здоров'я України (далі - 3ВО МО3 України) навчально-методичними матеріалами 3 дисциплін “Іноземна мова” та "Іноземна мова (за професійним спрямуванням)” для належної організації підготовки студентів до складання іспиту 3 англійської мови за професійним спрямуванням як окремої компоненти ЄДКІ.

Основна частина. Відповідно до листа МО3 України від 29.06.2017 року № 08.1-30/17662 “Про визначення рівня компетентності з іноземної мови професійного спрямування у студентів, громадян України, які навчаються за спеціальностями "Медицина”, “Стоматологія”, “Фармація” галузі знань 22 “Охорона здоров'я”, до ліцензійного іспиту “Крок 1. Стоматологія” 20.02.2018 року для студентів, громадян України, було включено субтест з тестових завдань іноземною мовою професійного спрямування, яку вивчав студент у ЗВО МОЗ України, з кожної дисципліни, що входить до змісту цього іспиту (далі - субтест).

За інформацією, отриманою від ДО “Центр тестування професійної компетентності фахівців 3 вищою освітою напрямів підготовки “Медицина” і “Фармація” при МОЗ України” (далі - Центр тестування МОЗ України), із 1856 студентів, які склали іспит, субтест не склали 1528 студентів, що становить $82 \%$.

Зважаючи на той факт, що загалом іспит "Крок 1. Стоматологія” у 2018 році не склали 42,7 \% студентів, з яких лише 7,8 \% (8 студентів) бюджетної форми навчання, можна зробити припущення про те, що суттєва причина такого “успіху” складання субтесту - у недостатньому рівні знань студентами іноземної мови (за професійним спрямуванням), зокрема навичок з фахового спілкування та знання термінології іноземною мовою з дев'яти дисциплін, які входять до іспиту “Крок 1. Стоматологія”. 
Найбільша кількість студентів ЗВО МОЗ України, які не склали субтест: в Одеському національному медичному університеті (86,0 \% із 93 студентів, які складали цей субтест); у ДВНЗ “Тернопільський державний медичний університет імені І. Я. Горбачевського МОЗ України” (86,0 \% із 129 студентів); у ВДНЗ України “Українська медична стоматологічна академія” (85,3 \% із 313 студентів); у ДВН3 “Івано-Франківський національний медичний університет” (83,2 \% із 131 студента). Найкращі успіхи продемонстрували студенти Д3 “Дніпропетровська медична академія МО3 України” (46,9 \% із 49 студентів) та Запорізького державного медичного університету (45,9 \% із 61 студента).

За дорученням Державної установи “Центральний методичний кабінет 3 вищої медичної освіти МОЗ України” (далі - ЦМК, лист від 18.04.2018 року № 23-01-9/89) ЗВО МОЗ України надали інформацію про середній бал успішності студентів спеціальності “Стоматологія” за підсумками вивчення ними дисциплін “Іноземна мова” та “Іноземна мова (за професійним спрямуванням)”, які складали субтест з іноземної мови за професійним спрямуванням у 2018 році.

Як свідчать отримані дані, практично у всіх ЗВО MO3 України успішність з дисципліни “Іноземна мова (за професійним спрямуванням)” вища за успішність з дисципліни “Іноземна мова” (табл. 1), що може свідчити про більшу зацікавленість студентів в опануванні навичок професійного спілкування іноземною мовою.

Чіткої залежності результатів складання субтесту іноземною мовою студентами того чи іншого закладу освіти від успішності з дисципліни “Іноземна мова (за професійним спрямуванням)” не виявлено. Наприклад, середній бал із зазначеної дисципліни - 3,6 і у студентів Д3 “Дніпропетровська медична академія МО3 України”, 46,9 \% з яких склали субтест, і у студентів Одеського національного медичного університету та ДВНЗ “Тернопільський державний медичний університет імені I. Я. Горбачевського МОЗ України”, з яких лише 14 \% склали цей тест. Також можна додати, що, як зазначено у таблиці 2, отриманій від Центру тестування МО3 України, найбільша кількість студентів, які показали найвищі результати по країні серед студентів, як у ВДНЗ України "Українська медична стоматологічна академія” (24 студенти - 13,6 \%), коли середній бал успішності з дисципліни “Іноземна мова (за професійним спрямуванням)” у цьому закладі - 3,47, так і у Львівському національному медичному університеті імені Данила Галицького (19 студентів - 10,8 \%), в якому середній бал успішності з дисципліни “Іноземна мова (за про-

Таблиця 1. Успішність студентів-стоматологів з дисциплін “Іноземна мова” та “Іноземна мова (за професійним спрямуванням)” у ЗВО МОЗ України порівняно з відсотком студентів, які не склали субтест іноземною мовою, у 2018 році

\begin{tabular}{|c|c|c|c|c|c|c|}
\hline \multirow[t]{2}{*}{$\begin{array}{c}\text { № } \\
\text { 3а/п }\end{array}$} & \multirow[t]{2}{*}{$\begin{array}{l}\text { Заклад } \\
\text { вищої } \\
\text { освіти }\end{array}$} & \multicolumn{2}{|c|}{$\begin{array}{c}\text { Середній бал успішності студентів } \\
\text { за підсумками вивчення } \\
\text { дисципліни “Іноземна мова” }\end{array}$} & \multicolumn{2}{|c|}{$\begin{array}{c}\text { Середній бал успішності студентів } \\
\text { за підсумками вивчення } \\
\text { дисципліни “Іноземна мова } \\
\text { (за професійним спрямуванням)” }\end{array}$} & \multirow{2}{*}{$\begin{array}{l}\text { Відсоток студен- } \\
\text { тів, які не склали } \\
\text { субтест іноземною } \\
\text { мовою }\end{array}$} \\
\hline & & $\begin{array}{c}\text { за 4-бальною } \\
\text { шкалою }\end{array}$ & $\begin{array}{c}\text { за 200-бальною } \\
\text { шкалою }\end{array}$ & $\begin{array}{c}\text { за 4-бальною } \\
\text { шкалою }\end{array}$ & $\begin{array}{c}\text { за 200-бальною } \\
\text { шкалою }\end{array}$ & \\
\hline 1 & БДМУ & 3,57 & - & 3,72 & - & 75,6 \\
\hline 2 & ВНМУ & 3,19 & 137,64 & 3,32 & 142,43 & 81,0 \\
\hline 3 & ДМА & 3,6 & 141 & 3,6 & 136 & 53,1 \\
\hline 4 & ДНМУ & 3,8 & 150 & 3,5 & 145 & 75,0 \\
\hline 5 & ЗДМУ & 4,01 & 160 & 4,05 & 162 & 54,1 \\
\hline 6 & ІФНМУ & - & 151,34 & - & 158,01 & 83,2 \\
\hline 7 & ЛНМУ & 4,1 & 145,7 & 4,4 & 155,8 & 79,6 \\
\hline 8 & ЛДМУ & 4,0 & 150,2 & 4,29 & 150,1 & 71,4 \\
\hline 9 & HMY & 3,24 & - & 3,36 & - & \\
\hline 10 & OHМУ & 3,26 & 130,4 & 3,61 & 144,57 & 86,0 \\
\hline 11 & ТДМУ & 3,0 & - & 3,6 & - & 86,0 \\
\hline 12 & УМCA & 3,10 & 125 & 3,47 & 138 & 85,3 \\
\hline 13 & ХНМУ & 3,28 & 142 & 3,40 & 146 & 82,4 \\
\hline
\end{tabular}


фесійним спрямуванням)” - 4,4, та Запорізькому державному медичному університеті і ДВНЗ “Івано-Франківський національний медичний університет” (16 студентів - 9,1 \%), в яких середній бал успішності з дисципліни “Іноземна мова (за професійним спрямуванням)”- 4,05 та 4,00 відповідно.

Найвищий середній бал успішності з дисципліни “Іноземна мова (за професійним спрямуванням)”у студентів Львівського національного медичного університету імені Данила Галицького $(4,4)$, а відсоток студентів, які не склали субтест, - 79,6 \%, і тільки 4 студенти (2,3 \%) увійшли до категорії “10 \% студентів, які показали найвищі результати складання субтесту”. Серед 8 студентів, які продемонстрували найвищі індивідуальні результати складання субтесту по країні, і студентка Вінницького національного медичного університету імені М. І. Пирогова К. І. Бондарчук (результат складання $-100 \%$, середній бал успішності з дисципліни “Іноземна мова (за професійним спрямуванням)” у цьому навчальному закладі - 3,3, середній відсоток студентів, які не склали субтест, - 81,0), і студент ДВН3 “Тернопільський державний медичний університет імені І. Я. Горбачевського МОЗ України” М. М. Якимчук (результат складання - 96,2 \%, середній бал успішності з дисципліни “Іноземна мова (за професійним спрямуванням)” у цьому навчальному закладі - 3,6, середній відсоток студентів, які не склали субтест, - 86,0), і студентка Одеського національного медичного університету А. П. Антонюк (результат складання - 96,2 \%, середній бал успішності з дисципліни “Іноземна мова (за професійним спрямуванням)” у цьому навчальному закладі - 3,6, середній відсоток студентів, які не склали субтест, - 86,0).

Можливо, більш чітка “залежність успіху” складання субтесту від оцінки, отриманої за підсумками вивчення іноземної мови за професійним спрямуванням, була б виявлена під час проведення порівняння її у тих студентів, хто склав і не склав субтест.

Обговорюючи результати складання студентами, громадянами України, субтесту з іноземної мови професійного спрямування ліцензійного іспиту “Крок 1. Стоматологія” 20.02.2018 року, необхідно врахувати те, що цей іспит складали студенти, які навчались за навчальним планом підготовки фахівців освітньо-кваліфікаційного рівня "Спеціаліст" кваліфікації “Лікар-стоматолог” за спеціальністю 7.110106 “Стоматологія”, затвердженим наказом МО3 України від 08.07.2010 року № 541, із зміна-
Таблиця 2. 10 \% студентів, які показали найвищі результати складання субтесту

\begin{tabular}{|l|c|c|}
\hline \multicolumn{1}{|c|}{ ЗВО } & $\begin{array}{c}\text { Кількість } \\
\text { студентів }\end{array}$ & $\begin{array}{c}\text { Відсоток у цій } \\
\text { категорії }\end{array}$ \\
\hline УМСА & 24 & 13,6 \\
\hline ЛНМУ & 19 & 10,8 \\
\hline ЗДМУ & 16 & 9,1 \\
\hline ІФНМУ & 16 & 9,1 \\
\hline ВНМУ & 15 & 8,5 \\
\hline ДМА & 15 & 8,5 \\
\hline ТДМУ & 12 & 6,8 \\
\hline ХНМУ & 12 & 6,8 \\
\hline БДМУ & 11 & 6,3 \\
\hline СДУ & 10 & 5,7 \\
\hline ОНМУ & 7 & 4,0 \\
\hline КМУ & 6 & 3,4 \\
\hline ДНМУ & 4 & 2,3 \\
\hline УжНУ & 3 & 1,7 \\
\hline МАЕМ & 2 & 1,1 \\
\hline ЛМІ & 2 & 1,1 \\
\hline ЛугДМУ & 1 & 0,6 \\
\hline МГУ & 1 & 0,6 \\
\hline Всього & 176 & 100 \\
\hline
\end{tabular}

ми, внесеними 24.03.2015 року, для забезпечення реалізації у діяльності ЗВО МОЗ України вимог абзацу третього частини другої статті 56 “Робочий час науково-педагогічних, наукових і педагогічних працівників” та частини сьомої розділу XV “Прикінцеві та перехідні положення” Закону України “Про вищу освіту”.

Наступного року відповідно до Постанови від 28.03.2018 року іспит з англійської мови за професійним спрямуванням будуть складати здобувачі освітнього ступеня “Магістр”. До 01.09.2019 року оцінюється рівень професійної компетентності 3 іноземної мови професійного спрямування, яку вивчав студент у закладі вищої освіти.

Натепер ще не завершена робота з розробки та затвердження стандартів вищої освіти для кожного рівня вищої освіти в межах кожної спеціальності з урахуванням пропозицій галузевих державних органів, до сфери управління яких належать вищі навчальні заклади, та галузевих об'єднань організацій роботодавців на виконання статті 10 Закону України “Про вищу освіту”.

Студенти ЗВО МОЗ України навчаються за примірними навчальними планами підготовки фахівців другого (магістерського) рівня вищої освіти галузі знань 22 “Охорона здоров'я” у вищих навчальних закладах МОЗ України за спеціальностями 222 “Медицина”, 
221 “Стоматологія”, 226 “Фармація”, затвердженими МО3 України 26.07.2016 року, та за спеціальністю 225 “Медична психологія”, затвердженим МОЗ України 01.06.2017 року, які розроблені робочими групами з підготовки пропозицій до стандартів вищої освіти за спеціальностями галузі знань “Охорона здоров’я”, визначеними у наказі МОЗ України від 09.11.2015 року № 733 “Про утворення координаційної та робочих груп для формування переліку спеціалізацій тапропозицій до стандартів вищої освіти за спеціальностями галузі знань “Охорона здоров’я”.
Здобувачі вищої освіти мають змогу, окрім нормативних дисциплін “Іноземна мова” та “Іноземна мова (за професійним спрямуванням)”, опановувати і курси за вибором “Іноземна мова (друга)” та “Іноземна мова (за професійним спрямуванням)” протягом 2-5 (4) років навчання для спеціальності “Медицина” та 2-4 років навчання - для спеціальності “Стоматологія” (табл. 3).

Якщо порівнювати обсяги навчальних годин, передбачені на вивчення іноземної мови у 2017/2018 навчальному році та у наступному 2018/2019 на-

Таблиця 3. Обсяги навчальних годин на вивчення іноземної мови у навчальних планах підготовки фахівців другого (магістерського) рівня вищої освіти галузі знань 22 “Охорона здоров’я”

\begin{tabular}{|c|c|c|c|c|c|c|}
\hline \multirow{3}{*}{$\begin{array}{l}\text { Назва дисци- } \\
\text { пліни }\end{array}$} & \multirow{3}{*}{$\begin{array}{l}\text { Рік на- } \\
\text { вчання }\end{array}$} & \multicolumn{5}{|c|}{$\begin{array}{c}\text { Обсяги навчальних годин на вивчення дисциплін } \\
\text { (курсів за вибором) }\end{array}$} \\
\hline & & \multicolumn{5}{|c|}{ спеціальність } \\
\hline & & $\begin{array}{c}222 \\
\text { “Медицина” }\end{array}$ & $\begin{array}{c}221 \\
\text { “Стоматологія” }\end{array}$ & $\begin{array}{c}226 \\
\text { “Фармація” }\end{array}$ & $\begin{array}{l}225 \text { “Медична } \\
\text { психологія” }\end{array}$ & 228 “Педіатрія” \\
\hline Іноземна мова & 1 & $\begin{array}{l}90 \text { год, } \\
50 \text { ауд. }\end{array}$ & $\begin{array}{l}90 \text { год, } \\
50 \text { ауд. }\end{array}$ & $\begin{array}{l}90 \text { год, } \\
50 \text { ауд. }\end{array}$ & $\begin{array}{l}90 \text { год, } \\
50 \text { ауд. }\end{array}$ & $\begin{array}{l}90 \text { год, } \\
50 \text { ауд. }\end{array}$ \\
\hline \multirow{2}{*}{$\begin{array}{l}\text { Іноземна мова } \\
\text { (за професійним } \\
\text { спрямуванням) }\end{array}$} & 1 & - & $\begin{array}{l}90 \text { год, } \\
30 \text { ауд. }\end{array}$ & - & - & - \\
\hline & 2 & $\begin{array}{l}180 \text { год, } \\
70 \text { ауд. }\end{array}$ & - & $\begin{array}{l}90 \text { год, } \\
30 \text { ауд. }\end{array}$ & $\begin{array}{l}90 \text { год, } \\
40 \text { год }\end{array}$ & $\begin{array}{l}180 \text { год, } \\
70 \text { ауд. }\end{array}$ \\
\hline \multicolumn{7}{|c|}{ Курси за вибором } \\
\hline \multirow[t]{2}{*}{ Англійська мова } & 1 & - & - & $\begin{array}{l}90 \text { год, } \\
50 \text { ауд. }\end{array}$ & - & - \\
\hline & 2 & - & - & $\begin{array}{c}120 \text { год, } \\
40 \text { ауд. }\end{array}$ & - & - \\
\hline \multirow[t]{2}{*}{$\begin{array}{l}\text { Іноземна мова } \\
\text { (друга) }\end{array}$} & 2 & $\begin{array}{c}120 \text { год, } \\
20 \text { ауд. }\end{array}$ & $\begin{array}{l}90 \text { год, } \\
30 \text { ауд. }\end{array}$ & - & - & $\begin{array}{c}120 \text { год, } \\
20 \text { ауд. }\end{array}$ \\
\hline & 3 & $\begin{array}{l}90 \text { год, } \\
20 \text { ауд. }\end{array}$ & $\begin{array}{l}90 \text { год, } \\
20 \text { ауд. }\end{array}$ & - & - & $\begin{array}{l}90 \text { год, } \\
20 \text { ауд. }\end{array}$ \\
\hline \multirow{3}{*}{$\begin{array}{l}\text { Іноземна мова } \\
\text { (за професійним } \\
\text { спрямуванням) }\end{array}$} & 3 & $\begin{array}{l}90 \text { год, } \\
20 \text { ауд. }\end{array}$ & $\begin{array}{l}90 \text { год, } \\
20 \text { ауд. }\end{array}$ & - & - & $\begin{array}{l}90 \text { год, } \\
20 \text { ауд. }\end{array}$ \\
\hline & 4 & $\begin{array}{l}90 \text { год, } \\
20 \text { ауд. }\end{array}$ & $\begin{array}{l}90 \text { год, } \\
20 \text { ауд. }\end{array}$ & - & - & $\begin{array}{l}90 \text { год, } \\
20 \text { ауд. }\end{array}$ \\
\hline & 5 & $\begin{array}{l}90 \text { год, } \\
20 \text { ауд. }\end{array}$ & - & - & - & $\begin{array}{l}90 \text { год, } \\
20 \text { ауд. }\end{array}$ \\
\hline \multicolumn{7}{|c|}{ Всього годин } \\
\hline & & $\begin{array}{l}750 \text { год, } \\
220 \text { ауд. }\end{array}$ & $\begin{array}{l}540 \text { год, } \\
170 \text { ауд. }\end{array}$ & $\begin{array}{l}390 \text { год, } \\
170 \text { ауд. }\end{array}$ & $\begin{array}{c}180 \text { год, } \\
90 \text { ауд. }\end{array}$ & $\begin{array}{l}750 \text { год, } \\
220 \text { ауд. }\end{array}$ \\
\hline
\end{tabular}

вчальному році, то необхідно зазначити, що у навчальному плані підготовки студентів-магістрів за спеціальністю “Стоматологія” загальна кількість годин - 540 (з них - 170 ауд.) дещо збільшилась, однак це збільшення відбулось за рахунок кількості навчальних годин на вивчення дисципліни “Іноземна мова (за професійним спрямуванням)” (90 год, 3 них 30 ауд., порівняно із 60 год, 3 них 30 ауд. у навчальному плані 2015 року) та курсів за вибором, при зменшенні навчального часу на вивчення дисципліни “Іноземна мова” (90 год, з них 50 ауд., та 180 год, з них 70 ауд. відповідно) (табл. 4).

Але успіхи студентів в опануванні дисципліни визначаються не тільки кількістю навчальних годин, 
Таблиця 4. Обсяги навчальних годин, передбачені на вивчення іноземної мови, у навчальних планах додипломної підготовки стоматологів

\begin{tabular}{|c|c|c|c|c|c|c|c|c|c|}
\hline \multirow{3}{*}{ Назва програми } & \multirow{2}{*}{\multicolumn{3}{|c|}{$\begin{array}{c}\text { За навчальним планом } \\
\text { другого (магістерського) } \\
\text { рівня вищої освіти }\end{array}$}} & \multicolumn{6}{|c|}{$\begin{array}{c}\text { За навчальним планом підготовки студентів } \\
\text { освітньо-кваліфікаційного рівня “Спеціаліст” }\end{array}$} \\
\hline & & & & \multicolumn{3}{|c|}{$\begin{array}{l}\text { скорегований, } \\
2015 \text { рік }\end{array}$} & \multicolumn{3}{|c|}{2010 рік } \\
\hline & курс & $\begin{array}{r}\text { всього } \\
\text { годин }\end{array}$ & ауд. & курс & $\begin{array}{l}\text { всього } \\
\text { годин } \\
\end{array}$ & ауд. & курс & $\begin{array}{c}\text { всього } \\
\text { годин } \\
\end{array}$ & ауд. \\
\hline Іноземна мова & 1 & 90 & 50 & 1 & 180 & 70 & 1 & 180 & 90 \\
\hline $\begin{array}{l}\text { Іноземна мова (за професійним } \\
\text { спрямуванням) }\end{array}$ & 1 & 90 & 30 & 2 & 60 & 30 & 2 & 90 & 40 \\
\hline $\begin{array}{l}\text { Іноземна мова (друга) (курс за } \\
\text { вибором) }\end{array}$ & 2 & 90 & 30 & 2 & 60 & 20 & 2 & 60 & 30 \\
\hline $\begin{array}{l}\text { Іноземна мова (друга) } \\
\text { (курс за вибором) }\end{array}$ & 3 & 90 & 20 & 3 & 60 & 20 & 3 & 60 & 30 \\
\hline $\begin{array}{l}\text { Іноземна мова за професійним } \\
\text { спрямуванням (курс за вибором) }\end{array}$ & 3 & 90 & 20 & 3 & 60 & 20 & 3 & 60 & 30 \\
\hline $\begin{array}{l}\text { Іноземна мова за професійним } \\
\text { спрямуванням (курс за вибором) }\end{array}$ & 4 & 90 & 20 & 4 & 60 & 20 & 4 & 60 & 30 \\
\hline Всього & & 540 & 170 & & 480 & 180 & & 510 & 250 \\
\hline
\end{tabular}

але й належною організацією навчального процесу, матеріально-технічного і навчально-методичного забезпечення запровадження інноваційних технологій навчання, фаховим рівнем викладачів та вмотивованістю студентів.

Так, відповідно до доручення ЦМК (лист від 17.04.2018 року № 23-01-9/88), опорною кафедрою іноземних мов Національного фармацевтичного університету опрацьовано низку пропозицій щодо покращення викладання дисципліни, серед яких: “... використовувати під час викладання дисципліни “Іноземна мова” навчально-методичні матеріали, які орієнтовані на останні досягнення у фармацевтичній галузі, та враховувати типові ситуації, характерні для професійної комунікації майбутніх працівників фармацевтичного сектору; ... запроваджувати у навчальний процес інноваційні технології навчання, зокрема: граматико-перекладну, аудіовізуальну, комунікативно-розвивальну, особистісно-орієнтовану, проектну, інтенсивну, інформаційну, ситуативного моделювання, ігрові й технології мовного портфоліо”.

Серед пропозицій, наданих опорною кафедрою Львівського національного медичного університету імені Данила Галицького, зазначено потребу у виокремленні підготовки до субтесту з тестових завдань іноземною мовою професійного спрямування ліцензійного іспиту “Крок 1” та екзамену 3 англійської мови професійного спрямування як складової державного кваліфікаційного іспиту як окреме завдання дисципліни; включенні підготовки до субтесту з тестових завдань іноземною мовою професійного спрямування ліцензійного іспиту “Крок 1” до переліку конкретних цілей кожного практичного заняття “Самостійна робота студента”.

Детальніше пропозиції опорних кафедр щодо вдосконалення викладання дисциплін “Іноземна мова” та “Іноземна мова (за професійним спрямуванням)”, а також “Іноземна мова за професійним спрямуванням (курс за вибором)” для забезпечення підготовки студентів до складання субтесту з тестових завдань іноземною мовою професійного спрямування ліцензійного іспиту “Крок 1” та екзамену з англійської мови професійного спрямування як складової державного кваліфікаційного іспиту будуть обговорені на нараді проректорів, присвяченій зазначеній проблемі.

Запровадження іспиту з англійської мови за професійним спрямуванням як окремого компонента ЄДКІ, безумовно, додасть мотивації для вивчення зазначеної дисципліни і студентам, і викладачам.

Для забезпечення вивчення дисципліни “Іноземна мова (за професійним спрямуванням)” здобувачами освітнього ступеня “Магістр” за спеціальностями галузі знань “Охорона здоров’я” фахівцями профільних опорних кафедр підготовлені програми нового покоління, які містять розділ щодо компетентностей та результатів навчання, формуванню яких сприяє дисципліна. Наприклад, у примірній програмі навчальної дисципліни “Іноземна мова за 
професійним спрямуванням” підготовки фахівців другого (магістерського) рівня вищої освіти спеціальності 221 “Стоматологія”, розробленій опорною кафедрою латинської та іноземних мов Львівського національного медичного університету імені Данила Галицького (обговорена на міжкафедральній нараді фахівців однопрофільних кафедр 09.09.2016 року та погоджена МОЗ України 05.10.2016 року), зазначено, що студент під час вивчення дисципліни “Іноземна мова (за професійним спрямуванням)” має набути таких спеціальних компетентностей, як:

- здатність коректного використання структурнолексичних аспектів іноземної мови спеціальності у процесі навчання та професійної діяльності;

- здатність організовувати практичну діяльність на основі знань про основні проблеми ротової порожнини іноземною мовою;

- здатність застосування іноземної мови під час професійної діяльності на робочому місці, в адміністративних закладах охорони здоров'я та університетських лікарнях в іншомовному середовищі;

- здатність проведення стоматологічної консультаціїв в іншомовному середовищі, володіння іноземною мовою на варіативно-адаптивному рівні під час міжособистісної взаємодії у професійному середовищі; - здатність ефективного використання іноземної мови під час оформлення історії хвороби пацієнта, встановлення діагнозу, призначення лікування, виписування рецепта, надання професійних консультацій щодо профілактики стоматологічних захворювань, належної гігієни ротової порожнини;

- здатність здійснення усного та письмового перекладу науково-медичної літератури іноземною та рідною мовами;

- здатність проведення наукових досліджень, розуміння оригінальної літератури іноземною мовою на стоматологічну тематику, інтерпретації змісту загальнонаукової літератури іноземною мовою;

- здатність використання засобів сучасних інформаційних технологій під час спілкування іноземною мовою та передачі інформації;

- здатність використовувати іноземну мову спеціальності на належному рівні; дотримання граматичних норм іноземної мови;

- здатність належної морально-етичної поведінки та професійної діяльності, дотримання громадянських прав та обов'язків, підвищення загальноосвітнього культурного рівня.

Опановуючи дисципліну “Іноземна мова”, студент вивчає такі теми, як: “Стоматологічні спеці- альності”, “Стоматологічні інструменти”, “Анатомія голови”, “Ротова порожнина”, “Анатомія зуба”, “Типи зубів”, “Аномалії розвитку зубів”, “Стоматологічний анамнез”, “Огляд ротової порожнини”, “Стоматологічна анестезія”.

Дисципліна "Іноземна мова (за професійним спрямуванням)” передбачає вивчення тем: "Карієс”, “Хвороби пульпи”, “Пломби”, “Коронки”, “Зубні протези”, “Лікування каналів кореня зуба”, “Видалення зубів”, “Імпланти”.

З урахуванням розроблених опорними кафедрами примірних програм, профільні кафедри ЗВО МОЗ України розробили робочі програми.

Як свідчать дані, отримані на запит ЦМК від 16.04.2018 року № 23-01-9/86, відсоток студентів ЗВО МОЗ України, які вивчають англійську мову, - в межах від 54,5 \% (2 курс Національного фармацевтичного університету) до 100 \% (на усіх факультетах Запорізького державного медичного університету). Додатково до вивчення іноземної мови як нормативної дисципліни на 1 курсі обрали курс за вибором “Іноземна мова” тільки студенти трьох навчальних закладів: 89,0 \% студентів спеціальності “Стоматологія”, 34,0 \% - спеціальності “Фармація” та 12,0 \% - спеціальності "Медицина” у ДВНЗ “Івано-Франківський національний медичний університет” і 40,6 \% студентів 1 курсу спеціальності “Фармація”, 16,9 \% - спеціальності “Медицина” та 19,0 \% студентів 1 й 2 курсів відповідно спеціальності “Медицина” (табл. 5).

У навчальних планах додипломної підготовки магістрів вищезазначених спеціальностей передбачено і вивчення курсів за вибором "Іноземна мова (друга)”. Однак, як свідчать дані, отримані від 3ВО МО3 України, тільки по 3 студенти $(0,7 \%)$ у Д3 “Дніпропетровська медична академія МО3 України” та ДВНЗ “Івано-Франківський національний медичний університет” обрали курс за вибором “Іноземна мова (друга), англійська” та 14 студентів (77,0 \%) Львівського національного медичного університету імені Данила Галицького. Це все студенти другого курсу медичних факультетів.

Зрозуміло, що для належного забезпечення такого контингенту навчальною літературою у бібліотеках навчальних закладів має бути достатня кількість підручників, посібників, словників тощо, виданих англійською мовою.

Забезпечення усіх навчальних дисциплін підручниками, навчальними посібниками, довідковою літературою тощо з розрахунку: один примірник 
Таблиця 5. Кількість (відсоток) студентів, які вивчають дисципліни “Іноземна мова”, “Іноземна мова (за професійним спрямуванням)” та курс за вибором “Іноземна мова” (англійська)

$$
\text { у ЗВО МОЗ України }
$$

\begin{tabular}{|c|c|c|c|c|c|c|c|c|}
\hline \multirow[t]{2}{*}{$3 \mathrm{BO}$} & \multirow[t]{2}{*}{ Спеціальність } & \multirow[t]{2}{*}{ Курс } & \multicolumn{2}{|c|}{ Іноземна мова } & \multicolumn{2}{|c|}{$\begin{array}{c}\text { Іноземна мова } \\
\text { (за професійним } \\
\text { спрямуванням) }\end{array}$} & \multicolumn{2}{|c|}{$\begin{array}{c}\text { Іноземна мова } \\
\text { (курс за вибором) }\end{array}$} \\
\hline & & & К-СТь & $\%$ & K-СТЬ & $\%$ & К-СТЬ & $\%$ \\
\hline \multirow[t]{6}{*}{ БДМУ } & \multirow[t]{2}{*}{ Медицина } & 1 & 310 & 85,2 & - & - & - & - \\
\hline & & 2 & - & - & 372 & 82,8 & - & - \\
\hline & Стоматологія & 1 & 70 & 92,1 & 70 & 92,1 & - & - \\
\hline & Медична психологія & 2 & - & - & 9 & 100,0 & - & - \\
\hline & \multirow[t]{2}{*}{ Фармація } & 1 & 47 & 82,5 & - & - & - & - \\
\hline & & 2 & - & - & 69 & 84,2 & - & - \\
\hline \multirow[t]{8}{*}{ BHMУ } & \multirow[t]{2}{*}{ Медицина } & 1 & 659 & 95,1 & - & - & - & - \\
\hline & & 2 & - & - & 704 & 94,0 & - & - \\
\hline & Педіатрія & 1 & 62 & 100,0 & - & - & - & - \\
\hline & Стоматологія & 1 & 109 & 97,2 & 109 & 97,2 & - & - \\
\hline & \multirow[t]{2}{*}{ Медична психологія } & 1 & 10 & 100,0 & - & - & - & - \\
\hline & & 2 & - & - & 8 & 100,0 & - & - \\
\hline & \multirow[t]{2}{*}{ Фармація } & 1 & 31 & 86,1 & - & - & - & - \\
\hline & & 2 & - & - & 53 & 98,2 & - & - \\
\hline \multirow[t]{5}{*}{ ДМА } & \multirow[t]{2}{*}{ Медицина } & 1 & 369 & 95,0 & - & - & - & - \\
\hline & & 2 & - & - & 402 & 96,0 & - & - \\
\hline & Стоматологія & 1 & 72 & 95,0 & 72 & 95,0 & - & - \\
\hline & \multirow[t]{2}{*}{ Фармація } & 1 & 12 & 92,0 & - & - & - & - \\
\hline & & 2 & - & - & 26 & 100,0 & - & - \\
\hline \multirow[t]{6}{*}{ ДНМУ } & \multirow[t]{2}{*}{ Медицина } & 1 & 324 & 100,0 & - & - & - & - \\
\hline & & 2 & - & - & 564 & 98,3 & - & - \\
\hline & \multirow[t]{2}{*}{ Стоматологія } & 1 & 20 & 100,0 & - & - & - & - \\
\hline & & 2 & - & - & 52 & 100,0 & - & - \\
\hline & \multirow[t]{2}{*}{ Фармація } & 1 & 14 & 100,0 & - & - & - & - \\
\hline & & 2 & - & - & 60 & 100,0 & - & - \\
\hline \multirow[t]{6}{*}{ ЗДМУ } & \multirow[t]{2}{*}{ Медицина } & 1 & 431 & 100,0 & - & - & - & - \\
\hline & & 2 & - & - & 462 & 100,0 & - & - \\
\hline & Педіатрія & 1 & 51 & 100,0 & - & - & - & - \\
\hline & Стоматологія & 1 & 49 & 100,0 & 49 & 100,0 & - & - \\
\hline & Фармація & 1 & 100 & 100,0 & - & - & 11 & 11,0 \\
\hline & & 2 & - & - & 156 & 100,0 & 115 & 74,0 \\
\hline ІФНМУ & Медицина & 1 & 292 & 89,0 & - & - & - & - \\
\hline & & 2 & - & - & 400 & 93,0 & 50 & 12,0 \\
\hline & Педіатрія & 1 & 39 & 83,0 & - & - & - & - \\
\hline & Стоматологія & 1 & 93 & 89,0 & 106 & 100,0 & 93 & 89,0 \\
\hline & Фармація & 1 & 30 & 73,0 & - & - & 14 & 34,0 \\
\hline & & 2 & 33 & 85,0 & - & - & - & - \\
\hline ЛНМУ & Медицина & 1 & - & - & 585 & 95,5 & 55 & 16,9 \\
\hline & & 2 & - & - & 520 & 93,0 & 54 & 19,0 \\
\hline & Педіатрія & 1 & 32 & 91,4 & - & - & - & - \\
\hline & Стоматологія & 1 & - & - & 150 & 95,4 & - & - \\
\hline & Фармація & 1 & - & - & 65 & 94,2 & 28 & 40,6 \\
\hline & & 2 & - & - & 76 & 97,4 & - & - \\
\hline
\end{tabular}


Продовження табл. 5

\begin{tabular}{|c|c|c|c|c|c|c|c|c|}
\hline \multirow[t]{3}{*}{ ЛДМУ } & Медицина & 1 & 70 & 100,0 & - & - & - & - \\
\hline & Педіатрія & 2 & 29 & 100,0 & 105 & 100,0 & - & - \\
\hline & Стоматологія & 1 & 10 & 100,0 & 10 & 100,0 & - & - \\
\hline \multirow{8}{*}{ HMY } & \multirow{2}{*}{ Медицина } & 1 & 972 & 94,5 & - & - & - & - \\
\hline & & 2 & - & - & 952 & 90,0 & - & - \\
\hline & Педіатрія & 1 & 154 & 100,0 & - & 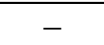 & $\begin{array}{llll}- & \\
\end{array}$ & - \\
\hline & Стоматологія & 1 & 273 & 97,5 & 273 & 97,5 & - & - \\
\hline & \multirow[t]{2}{*}{ Медична психологія } & 1 & 36 & 100,0 & - & - & - & - \\
\hline & & 2 & - & - & 16 & 100,0 & - & - \\
\hline & \multirow[t]{2}{*}{ Фармація } & 1 & 80 & 94,1 & - & - & - & - \\
\hline & & 2 & 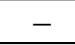 & - & 73 & 93,6 & - & - \\
\hline \multirow[t]{2}{*}{ НФаУ } & \multirow[t]{2}{*}{ Фармація } & 1 & 556 & 99,3 & - & - & - & - \\
\hline & & 2 & - & - & 305 & 54,5 & - & - \\
\hline \multirow{5}{*}{ OHMY } & \multirow[t]{2}{*}{ Медицина } & 1 & 427 & 94,9 & - & - & - & - \\
\hline & & 2 & - & - & 609 & 96,0 & - & - \\
\hline & Стоматологія & 1 & 61 & 93,9 & 61 & 93,9 & - & - \\
\hline & \multirow[t]{2}{*}{ Фармація } & 1 & 53 & 91,4 & - & - & - & - \\
\hline & & 2 & - & $\begin{array}{c}- \\
\end{array}$ & 53 & 81,5 & - & - \\
\hline \multirow[t]{5}{*}{ ТДМУ } & \multirow[t]{2}{*}{ Медицина } & 1 & 352 & 98,6 & - & $\begin{array}{ll}- \\
\end{array}$ & - & - \\
\hline & & 2 & 56 & 77,8 & 361 & 92,1 & - & - \\
\hline & Стоматологія & 1 & 83 & 95,4 & 83 & 95,4 & - & - \\
\hline & \multirow[t]{2}{*}{ Фармація } & 1 & 49 & 83,1 & - & - & - & - \\
\hline & & 2 & - & 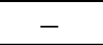 & 55 & 87,3 & - & - \\
\hline \multirow[t]{5}{*}{ УMCA } & \multirow[t]{2}{*}{ Медицина } & 1 & 315 & 94,9 & - & - & - & - \\
\hline & & 2 & - & 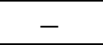 & 227 & 95,0 & - & - \\
\hline & \multirow[t]{2}{*}{ Педіатрія } & 1 & 28 & 100,0 & - & - & - & - \\
\hline & & 2 & - & - & 103 & 100,0 & - & - \\
\hline & \begin{tabular}{|l|} 
Стоматологія \\
\end{tabular} & 1 & 268 & 97,0 & 268 & 100,0 & - & - \\
\hline \multirow[t]{4}{*}{ XHMY } & \multirow[t]{2}{*}{ Медицина } & 1 & 422 & 96,8 & - & - & - & - \\
\hline & & 2 & - & - & 501 & 97,3 & - & - \\
\hline & \begin{tabular}{|l} 
Педіатрія \\
\end{tabular} & 1 & 57 & 100,0 & - & - & - & - \\
\hline & Стоматологія & 1 & 118 & 100,0 & 118 & 100,0 & - & - \\
\hline
\end{tabular}

на п’ятьох осіб фактичного контингенту студентів (п. 6 додатка 14 Ліцензійних умов) є необхідною умовою належного навчально-методичного забезпечення викладання усіх дисциплін, у тому числі іноземної мови, та виконання навчальним закладом Ліцензійних умов (додаток 6 до Ліцензійних умов).

Аналіз забезпечення студентів 3ВО МОЗ України навчальними книгами, який щороку здійснює ЦМК за даними від навчальних закладів на початку навчального року (станом на 1 вересня), свідчить про те, що у 2017/2018 навчальному році забезпечення навчальною книгою, виданою протягом останніх 5 років, дисциплін “Іноземна мова” та "Іноземна мова (за професійним спрямуванням)” потребує покращення (спеціальність “Медицина”: 49 \% підручниками та 14 \% посібниками; спеціальність “Стоматологія”: 67 \% підручника- ми та 14 \% посібниками; спеціальність “Фармація”: 64 \% підручниками та 30 \% посібниками) (табл. 6). У всіх навчальних закладах у достатній кількості закуплено, переважно, або підручник, або посібник.

За інформацією, наданою бібліотеками ЗВО МОЗ України (станом на 01.09.2017 року), студенти мають змогу вивчати дисципліну “Іноземна мова (за професійним спрямуванням)” за такими навчальними книгами:

Підручники:

1. “Англійська мова для студентів-медиків” (Л. Я. Аврахова, І. Ю. Паламаренко, Т. В. Яхно, 2015), наявний: у БДМУ, ЗДМУ, ЛДМУ, ВНМУ, ІФНМУ.

2. “Англійська мова за професійним спрямуванням для студентів-медиків” (О. С. Ісаєва, 
Таблиця 6. Стан забезпечення підручниками і посібниками студентів ЗВО МОЗ України з дисципліни “Іноземна мова (за професійним спрямуванням)” (\% підручниками/посібниками)

\begin{tabular}{|c|c|c|c|c|c|c|c|c|c|c|c|c|c|}
\hline $\begin{array}{c}\text { Назва дисципліни } \\
\text { (курсу) }\end{array}$ & 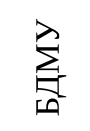 & 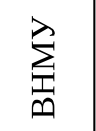 & $\sum^{\mathbb{E}}$ & 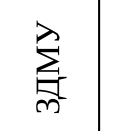 & $\sum_{\substack{\theta \\
\theta}}^{\lambda}$ & 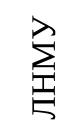 & $\sum_{\underline{I}}^{\lambda}$ & $\sum_{0}^{\lambda}$ & 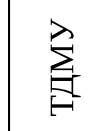 & $\sum_{\lambda}^{\overleftarrow{S}}$ & $\sum_{x}^{\lambda}$ & 灾良 & 守 范 \\
\hline \multicolumn{14}{|c|}{ Спеціальність “Медицина” } \\
\hline $\begin{array}{l}\text { Іноземна мова } \\
\text { (за професійним } \\
\text { спрямуванням) } \\
\text { англійська }\end{array}$ & 83/- & $100 /-$ & & $100 /-$ & $3 /-$ & $100 /$ & $100 /-$ & $100 /-$ & $-/ 100$ & & $-/ 41$ & $-/ 27$ & $49 / 14$ \\
\hline \multicolumn{14}{|c|}{ Спеціальність “Стоматологія” } \\
\hline $\begin{array}{l}\text { Іноземна мова } \\
\text { (за професійним } \\
\text { спрямуванням) } \\
\text { англійська }\end{array}$ & $100 /-$ & $100 /-$ & $100 /-$ & $100 /-$ & 7/- & $100 /$ & $100 /-$ & $100 /-$ & $-/ 100$ & $100 /-$ & $-/ 44$ & $-/ 27$ & $67 / 14$ \\
\hline \multicolumn{14}{|c|}{ Спеціальність “Фармація” } \\
\hline $\begin{array}{c}\text { Назва дисципліни } \\
\text { (курсу) }\end{array}$ & 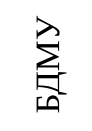 & 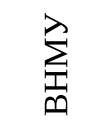 & $\frac{\mathbb{E}}{\sum^{-}}$ & 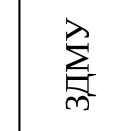 & & & 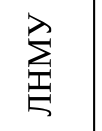 & $\sum_{\text {II }}^{\lambda}$ & $\sum_{0}^{\lambda}$ & 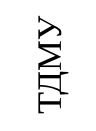 & 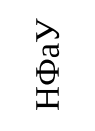 & 穴主 & نे \\
\hline $\begin{array}{l}\text { Іноземна мова } \\
\text { (за професійним } \\
\text { спрямуванням) } \\
\text { англійська }\end{array}$ & $100 /-$ & $100 /-$ & & $100 /-$ & & 100 & $100 /-$ & $100 /-$ & $100 /-$ & $-/ 100$ & $-/ 100$ & $-/ 27$ & $64 / 30$ \\
\hline
\end{tabular}

Л. Я. Аврахова, I. А. Прокоп та інші, 2013), наявний: у ЛНМУ, ВНМУ, НМУ.

3. “Англійська мова за професійним спрямуванням. Стоматологія” (І. Г. Романко, І. М. Сологор, 2015), наявний: у ЛДМУ, ТДМУ, ДМА, УМСА.

4. “Англійська мова для фармацевтів” (Л. Я. Аврахова та інші, 2017), наявний: у ЗДМУ, ІФНМУ.

5. “Англійська мова для фармацевтів та клінічних фармацевтів” (Н. В. Кучумова, 2017), наявний: у ЛНМУ, ІФНМУ.

6. “Підручник з англійської мови для студентів фармацевтичних факультетів” (Н. І. Войткевич, Л. І. Запоточна, О. М. Рак, 2016), наявний у БДМУ.

7. "English for Medical Students” (А. Г. Саблук, Л. В. Левандовський, 2015), наявний у ЛДМУ.

8. “Англійська мова за професійним спрямуванням” (Н. В. Косило, 2013), наявний в ІФНМУ.

Посібники:

1. “Англійська мова за професійним спрямуванням. Медицина” (I. А. Прокоп та інші, 2016, 2017), наявний у ТДМУ.

2. "Удосконалюємо професійне іншомовне спілкування” (М. І. Бобак, Н. В. Рокіцька, 2014, 2016), наявний: у ХНМУ, ТДМУ.

3. “Англійська мова для студентів-фармацевтів” (Н. Р. Венгринович, 2014, 2016), наявний в ІФНМУ.
4. “Словник фармацевтичних термінів для студентів і фахівців” (I. В. Ніженковська та інші, 2015), наявний у ТДМУ.

5. “Українсько-латинсько-англійський медичний енциклопедичний словник в 4 томах” (Л. І. Петрух, I. М. Головко, 2013), наявний: у ХНМУ, ЛДМУ.

6. “English in Proficiency” (L. A. Toryanyk, O. Krepak, 2016), наявний у НФаУ.

7. “Глосарій кардіологічних термінів: англоукраїнський для студентів-перекладачів і медиків” (В. В. Михайленко, С. І. Гречко, 2017), наявний у БДМУ.

8. "Міжнародна анатомічна термінологія" (В. Г. Черкасов та інші, 2010), наявний у ТДМУ.

Необхідно зауважити, що динаміка забезпечення підручниками і посібниками з усіх дисциплін студентів медичних факультетів 3ВО МОЗ України протягом 2012-2017 років свідчить про те, що цей показник у 2017/2018 навчальному році становить: підручниками - 45 \%, посібниками - $22 \%$, і суттєво не змінився порівняно із 2016/2017 навчальним роком (табл. 7).

Як і минулих років, найменш забезпеченим підручниками і посібниками є блок гуманітарних та соціально-економічних дисциплін (табл. 8).

3 метою покращення забезпечення студентів оновленою навчальною книгою ЗВО МОЗ України 
Таблиця 7. Динаміка забезпечення підручниками і посібниками студентів медичних факультетів 3ВО МОЗ України протягом 2012-2017 років (державна мова, термін використання - 5 років)

\begin{tabular}{|l|c|c|}
\hline \multicolumn{1}{|c|}{ Рік проведення обрахунків } & Забезпечення підручниками (\%) & Забезпечення посібниками (\%) \\
\hline 2012 & 37 & 39 \\
\hline 2013 & 35 & 30 \\
\hline 2014 & 34 & 18 \\
\hline $2015^{*}$ & 35 & 21 \\
\hline $2016^{* *}$ & 42 & 22 \\
\hline $2017^{* *}$ & 45 & \\
\hline
\end{tabular}

Примітки:

1. * - враховані навчально-методичні книги, які видані за дозволами вчених рад ЗВО МОЗ України та надійшли до фондів бібліотек з вересня 2014 року, з розрахунку: одна навчальна книга на трьох студентів, що одночасно вивчають дану дисципліну (Ліцензійні умови надання освітніх послуг у сфері вищої освіти, затверджені наказом Міністерства освіти і науки України від 24.12.2003 року № 847).

2. ** - враховані навчально-методичні книги, які видані за дозволами вчених рад ЗВО МОЗ України та надійшли до фондів бібліотек з вересня 2014 року, з розрахунку: одна навчальна книга на п’ятьох студентів, що одночасно вивчають дану дисципліну (Ліцензійні умови провадження освітньої діяльності закладів освіти, затверджені Постановою Кабінету Міністрів України від 30.12.2015 року № 1187).

Таблиця 8. Забезпечення підручниками та посібниками по блоках дисциплін (спеціальність “Медицина”)

\begin{tabular}{|l|c|c|c|c|c|}
\hline & 2013 & 2014 & 2015 & 2016 & 2017 \\
\hline \multicolumn{7}{|c|}{ Гуманітарні та соціально-економічні дисципліни } \\
\hline Підручники, \% & 20 & 19 & 27 & 27 & 38 \\
\hline Посібники, \% & 30 & 23 & 14 & 9 & 16 \\
\hline \multicolumn{7}{|c|}{ Природничо-наукові дисципліни } \\
\hline Підручники, \% & 29 & 30 & 35 & 42 & 54 \\
\hline Посібники, \% & 24 & 16 & 15 & 22 & 24 \\
\hline \multicolumn{7}{|c|}{ Професійно-орієнтовані дисципліни } \\
\hline Підручники, \% & 39 & 36 & 36 & 43 & 44 \\
\hline Посібники, \% & 31 & 18 & 17 & 21 & 22 \\
\hline
\end{tabular}

вживали заходів для залучення коштів на видання та закупівлю навчально-методичної літератури.

3 дисципліни “Іноземна мова (за професійним спрямуванням)” у 2017 році було видано ряд нових книг:

“Англійська мова” (Н. В. Косило, І. Ф. Цебрук та інші), ІФНМУ;

“Підручник 3 англійської мови для студентів фармацевтичних факультетів” (друге видання, Н. І. Войткевич, Л. І. Запоточна, О. М. Рак), БДМУ;

“Англійська мова для фармацевтів та клінічних фармацевтів” (Н. В. Кучумова), ЛНМУ;

“Англійська мова для студентів-стоматологів” (Л. Я. Аврахова, І. Ю. Паламаренко, О. В. Голік), НМУ;

“Тлумачний словник термінів з медичної та біологічної фізики” (В. Г. Кнігавко, О. В. Зайцева та інші), ХНМУ;

“Українсько-англійсько-російський словник базових фізичних термінів” (В. В. Пащенко, В. Г. Гур’ янов та інші), НМУ;
“English reader for medical students” (Г. К. Волкова та інші), ЗДМУ;

"English for Dentistry Students: Teacher's Book" (Н. В. Кучумова, Л. В. Манюк), ЛНМУ;

“English for Medical Students: Teacher's Book" (Н. В. Кучумова, Л. В. Манюк), ЛНМУ;

"Короткий українсько-англійський словник культурологічної термінології з курсу “Історія України та української культури” (І. Ю. Робак, В. А. Альков), ХНМУ;

“Короткий українсько-англійський та англійськоукраїнський словник історико-культурологічної термінологї” (І. Ю. Робак, В. А. Альков), ХНМУ;

“Англійська мова для аспірантів медичних спеціальностей” (2 видання, I. Ф. Цебрук, Н. Р. Венгринович), ІФНМУ;

“English for Dentists” (Л. Я. Аврахова та інші), НМУ.

Необхідно зазначити, що значна частка навчальної літератури натепер видається у ЗВО МОЗ України невеликими тиражами за рахунок авторських та 
спонсорських коштів, але адміністрації у навчальних закладах вишукують і бюджетні кошти на закупівлю та видання книг.

Як свідчать дані, отримані на запит ЦМК від ЗВО МОЗ України, найбільша кількість коштів на закупівлю навчальної літератури у 2017 році була спрямована: у Вінницькому національному медичному університеті імені М. І. Пирогова (2 849 781,00 грн); Д3 “Дніпропетровська медична академія МО3 України” (1 924 180,00 грн); Харківському національному медичному університеті (1 406 847,50 грн) (табл. 9).

Таблиця 9. Дані про кошти, спрямовані 3ВО МОЗ України на закупівлю навчальної літератури протягом 2013-2017 років (грн)

\begin{tabular}{|l|c|c|c|c|c|}
\hline Назва ЗВО & 2013 рік & 2014 рік & 2015 рік & 2016 рік & 2017 рік \\
\hline БДМУ & 215127,40 & 439438,50 & 640930,00 & 639680,15 & 880342,52 \\
\hline ВНМУ & 653140,00 & 682064,00 & 956828,00 & 1013353,24 & 2849781,00 \\
\hline ДМА & 755970,00 & 824200,00 & 1215540,00 & 1571250,00 & 1924180,00 \\
\hline ЗДМУ & 426890,00 & 293600,00 & 2692704,00 & 2708990,00 & 1331067,00 \\
\hline ІФНМУ & 361029,73 & 297417,17 & 685386,13 & 1036591,04 & 1014088,87 \\
\hline ЛНМУ & 351555,00 & 458550,00 & 539476,27 & 907932,00 & 986090,00 \\
\hline НМУ & не надано & 331260,00 & 738375,00 & 72500,00 & 669572,84 \\
\hline НФУ & 686851,00 & 300611,00 & 566688,85 & 305656,50 & 187906,90 \\
\hline ОНМУ & 198500,00 & 392327,00 & 140077,00 & 821439,00 & 811329,29 \\
\hline ТДМУ & 57742,00 & 193510,00 & 503178,90 & 2119569,63 & 1395500,63 \\
\hline УМСА & 343189,00 & 479520,00 & 278170,00 & 582379,00 & 964830,00 \\
\hline ХНМУ & 768166,00 & 277580,00 & 794653,50 & 1937347,22 & 1406847,50 \\
\hline ЛДМУ & & & & & 595605,00 \\
\hline
\end{tabular}

Із розрахунку на 1 студента, як і минулого року, найбільше коштів на закупівлю літератури українською мовою залучено керівництвом ДВНЗ “Тернопільський державний медичний університет імені I. Я. Горбачевського МОЗ України” (504,52 грн), російською та іноземною мовами - Д3 “Дніпропетровська медична академія МО3 України” (606,28 грн та 635, 42 грн відповідно) (табл. 10) [4].

Найбільше коштів на видання навчальної літератури у 2017 році витрачено, як і минулого року, у Національному фармацевтичному університеті (1 500 371,50 грн, однак 3 них іноземною мовою тільки 0,1%) та ДВНЗ “Тернопільський державний медичний університет імені I. Я. Горбачевського MO3 України” (1 377 596,59 грн, з них іноземною мовою 17,0 \%) (табл. 11).

Ураховуючи нагальну потребу в покращенні підготовки студентів до складання у 2019 році ліцензійного іспиту “Крок 1”, який буде оцінювати як рівень професійної компетентності із фундаментальних дисциплін, так і з іноземної мови професійного спрямування, у таблиці 12 наведено інформацію про кількість найменувань навчальних книг, виданих англійською мовою, які були придбані у 2017 році, з дисциплін, що входять до змісту ліцензійного іспиту “Крок 1 ”.
Найбільша кількість 3ВО МОЗ України придбала навчальну літературу з біологічної хімії (10), патологічної фізіології (9) та нормальної фізіології (7). При цьому найбільшу кількість найменувань англомовних видань 3 дисциплін “Загальна лікарська підготовка”, що входять до ліцензійного іспиту “Крок 1”, з числа найменувань усіх придбаних англомовних видань закуплено у Запорізькому державному медичному університеті (16 із 100) та ДВНЗ “Івано-Франківський національний медичний університет” (7 із 53).

Найбільша кількість найменувань англомовних книг, виданих у 2017 році (табл. 13), теж у Запорізькому державному медичному університеті - 52, з них 6-з дисциплін “Загальна лікарська підготовка” ліцензійного іспиту “Крок 1”) та ВДНЗ “Буковинський державний медичний університет” (19, з них 2 - $з$ дисциплін “Загальна лікарська підготовка” ліцензійного іспиту “Крок 1”).

Всього у 2017 році було видано 20 найменувань навчальних книг англійською мовою, із 6 дисциплін, що входять до змісту дисциплін “Крок 1. Загальна лікарська підготовка”, та однієї-що входить до дисциплін “Крок 1. Фармація”, а також 82 найменування методичних рекомендацій, підготовлених англійською мовою. 


\begin{tabular}{|c|c|c|c|c|c|c|c|c|c|c|c|c|c|c|}
\hline \multirow{5}{*}{ 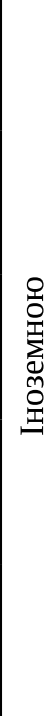 } & 롱 & $\mid \begin{array}{l}\vec{b} \\
-\hat{0} \\
-1\end{array}$ & 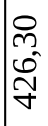 & & $\begin{array}{l}\hat{\infty} \\
\infty \\
\hat{i} \\
\hat{N}\end{array}$ & 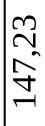 & 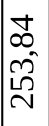 & $\begin{array}{l}\hat{0} \\
\hat{D} \\
-1\end{array}$ & $\begin{array}{l}0 \\
0 \\
6 \\
10\end{array}$ & & 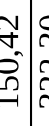 & & 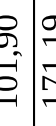 & \\
\hline & $\begin{array}{l}0 \\
\stackrel{2}{2}\end{array}$ & $\begin{array}{l}8 \\
\varnothing \\
\infty\end{array}$ & $\begin{array}{l}\infty \\
\infty \\
\mathscr{f}^{-} \\
-1\end{array}$ & & 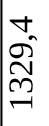 & $\begin{array}{l}\infty \\
\stackrel{2}{a} \\
\vec{A} \\
-1\end{array}$ & $\begin{array}{l}\hat{N} \\
-\hat{\Lambda} \\
\text { N }\end{array}$ & $\begin{array}{l}\infty \\
\infty \\
\infty\end{array}$ & مِ & & 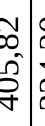 & & & \\
\hline & 足 & $\begin{array}{l}8 \\
8 \\
\text { î }\end{array}$ & 8 & $\begin{array}{l}\text { 员 } \\
\infty^{\circ} \\
\text { Nิ }\end{array}$ & 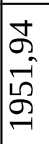 & $\begin{array}{l}\infty \\
\infty \\
\stackrel{\omega}{N}\end{array}$ & $\begin{array}{l}3 \\
10 \\
6 \\
0 \\
m\end{array}$ & $\begin{array}{l}8 \\
0 \\
\infty \\
-1\end{array}$ & $\mid \begin{array}{l}5 \\
9 \\
0\end{array}$ & & 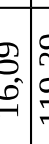 & & $\begin{array}{l}6 \\
\text { ta }\end{array}$ & \\
\hline & $\underset{\sim}{\vec{D}}$ & $\begin{array}{l}\mathscr{0} \\
\approx \\
\infty\end{array}$ & $\begin{array}{l}\text { 노 } \\
0 \\
0 \\
\sigma\end{array}$ & $\begin{array}{c}\bar{m} \\
6 \\
6\end{array}$ & $\begin{array}{l}8 \\
8 \\
00^{\circ} \\
i n\end{array}$ & $\begin{array}{l}\vec{A} \\
\vec{g} \\
\vec{q}\end{array}$ & \begin{tabular}{l}
8 \\
8 \\
\multirow{1}{*}{} \\
$\infty$
\end{tabular} & 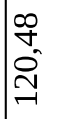 & $\mid \begin{array}{l}- \\
\infty \\
0 \\
-1\end{array}$ & & 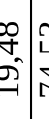 & & & \\
\hline & $\stackrel{m}{\stackrel{N}{\sim}}$ & $\begin{array}{l}8 \\
0 \\
10^{\circ}\end{array}$ & 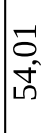 & $\begin{array}{l}\infty \\
2 \\
0\end{array}$ & \begin{tabular}{l}
$\theta$ \\
$\mathscr{0}$ \\
\multirow{1}{*}{}
\end{tabular} & $\begin{array}{l}\widehat{1} \\
0 \\
0 \\
0 \\
10\end{array}$ & $\begin{array}{l}\infty \\
\infty \\
\theta_{0}\end{array}$ & 胥 & 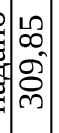 & & 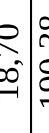 & & to & \\
\hline \multirow{5}{*}{ 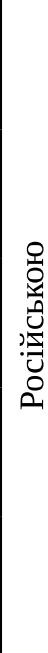 } & 穴 & 1 & 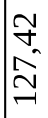 & 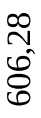 & $\begin{array}{l}8 \\
8 \\
\infty \\
\infty \\
\infty \\
-1\end{array}$ & 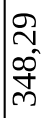 & 1 & $\begin{array}{l}m \\
\tilde{n} \\
\tilde{\tilde{N}} \\
\tilde{N}\end{array}$ & $\begin{array}{l}\dot{D} \\
\text { m. }\end{array}$ & 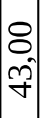 & 1 & & 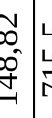 & 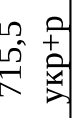 \\
\hline & $\begin{array}{l}0 \\
\stackrel{2}{\sim}\end{array}$ & $\begin{array}{l}0 \\
\text { Na } \\
0\end{array}$ & $\begin{array}{l}\vec{N} \\
\tilde{\sigma} \\
\vec{\sigma}\end{array}$ & $\begin{array}{l}\mathscr{D} \\
\infty \\
m^{2}\end{array}$ & $\begin{array}{l}8 \\
8 \\
6 \\
m \\
\end{array}$ & 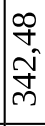 & 1 & 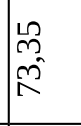 & 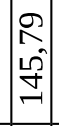 & 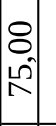 & 1 & & 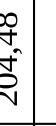 & \\
\hline & 농 & 1 & $\begin{array}{l}\infty \\
\infty \\
10 \\
0 \\
-1\end{array}$ & \begin{tabular}{l} 
مि \\
\multirow{N}{N}{} \\
in \\
\end{tabular} & 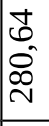 & 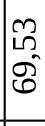 & 1 & 글 & $\begin{array}{l}\infty \\
\infty \\
\infty \\
\infty\end{array}$ & 童 & \begin{tabular}{c}
$c$ \\
0 \\
\hdashline \\
\hdashline
\end{tabular} & & $\begin{array}{l}-1 \\
\tilde{D}^{2} \\
\end{array}$ & \\
\hline & 范 & 1 & $\begin{array}{l}F \\
\dot{5} \\
\hat{N}\end{array}$ & $\begin{array}{l}\infty \\
m \\
\stackrel{m}{\square} \\
\stackrel{\Xi}{-}\end{array}$ & $\begin{array}{l}\curvearrowright \\
\wp \\
\infty\end{array}$ & $\vec{F}$ & \begin{tabular}{l}
8 \\
0 \\
\hdashline \\
-1
\end{tabular} & $\begin{array}{l}\stackrel{g}{q} \\
\hat{n} \\
\stackrel{m}{-}\end{array}$ & $\begin{array}{l}\vec{f} \\
\tilde{2} \\
\hat{N}\end{array}$ & \begin{tabular}{l}
8 \\
0 \\
0 \\
\hdashline
\end{tabular} \mid & 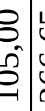 & & $\frac{\infty}{N}$ & \\
\hline & $\stackrel{m}{\stackrel{\sim}{N}}$ & I & 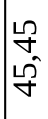 & $\begin{array}{l}6 \\
-1 \\
8\end{array}$ & $\stackrel{\text { q }}{\stackrel{+}{i}}$ & 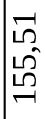 & $\begin{array}{l}8 \\
\text { O } \\
\infty\end{array}$ & 옾 & ลิ & & 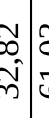 & & ह & \\
\hline \multirow{5}{*}{ 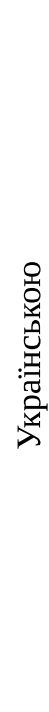 } & $\overrightarrow{\stackrel{े}{~}}$ & 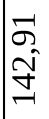 & 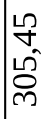 & ํㅗ & $\begin{array}{l}8 \\
\dot{-} \\
-1\end{array}$ & $\begin{array}{l}\hat{N} \\
\hat{b}^{\circ} \\
\omega \\
-1\end{array}$ & \begin{tabular}{l}
$\hat{\infty}$ \\
$\infty$ \\
\multirow{\theta}{|}{}
\end{tabular} & 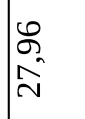 & $\mid \begin{array}{l}\infty \\
\mathfrak{c} \\
\infty \\
-0 \\
-1\end{array}$ & 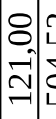 & 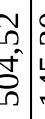 & & 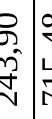 & 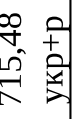 \\
\hline & $\begin{array}{l}0 \\
\stackrel{\sim}{\sim}\end{array}$ & 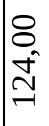 & $\begin{array}{l}\infty \\
0 \\
\hat{\tilde{O}} \\
-1\end{array}$ & $\begin{array}{l}\infty \\
\hat{0} \\
\hat{A} \\
\hat{N}\end{array}$ & 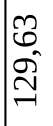 & 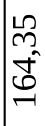 & $\begin{array}{l}\infty \\
0 \\
\infty \\
m \\
\end{array}$ & 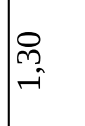 & $\left|\begin{array}{c}0 \\
\hat{2} \\
0 \\
\tilde{n}\end{array}\right|$ & $\begin{array}{l}8 \\
0 \\
\hat{m} \\
-1 \\
\end{array}$ & 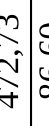 & & $\begin{array}{l}0 \\
0 \\
0 \\
0 \\
\end{array}$ & \\
\hline & $\stackrel{\text { Da }}{\stackrel{N}{人}}$ & $\begin{array}{l}8 \\
0 \\
0 \\
-1 \\
-1\end{array}$ & 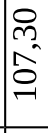 & $y$ & $\begin{array}{l}\text { ஸे } \\
\hat{\Omega} \\
8\end{array}$ & $\begin{array}{l}\text { 엉 } \\
\text { กิ }\end{array}$ & $\begin{array}{l}\stackrel{g}{+} \\
\stackrel{y}{=}\end{array}$ & $\begin{array}{l}\hat{\sigma} \\
\hat{n}\end{array}$ & 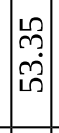 & & 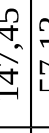 & & 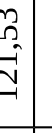 & \\
\hline & $\stackrel{\nabla}{\vec{i}}$ & $\begin{array}{l}\infty \\
\infty \\
\infty \\
\infty\end{array}$ & \begin{tabular}{l}
$\infty$ \\
$\infty$ \\
\multirow{2}{N}{}
\end{tabular} & $\infty^{\infty}$ & 早 & $\begin{array}{l}n \\
m \\
\bar{n}\end{array}$ & $\mid \begin{array}{l}8 \\
\infty \\
\infty\end{array}$ & 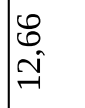 & $\mid \begin{array}{l}0 \\
0 \\
\tilde{m} \\
\mathbf{m}\end{array}$ & $\left|\begin{array}{l}8 \\
8 \\
\infty \\
0 \\
1\end{array}\right|$ & $\begin{array}{c}7 \\
\end{array}$ & & S. & \\
\hline & $\stackrel{m}{\stackrel{n}{*}}$ & $\begin{array}{l}8 \\
0 \\
6\end{array}$ & $\begin{array}{l}2 \\
0 \\
8 \\
0 \\
-1\end{array}$ & & 농 & \begin{tabular}{l}
$\stackrel{2}{2}$ \\
\multirow{f}{6}{}
\end{tabular} & $\begin{array}{l}\text { 足 } \\
\text { ô } \\
0^{\circ}\end{array}$ & 옾 & 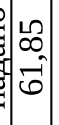 & & 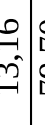 & & 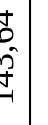 & \\
\hline & & 站 & 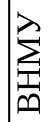 & & $m$ & 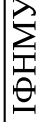 & $\sum_{\text {至 }}^{2}$ & $\sum_{i}^{\lambda}$ & $\left|\begin{array}{l}\overrightarrow{\hat{\theta}} \\
\mathbf{\imath}\end{array}\right|$ & 行 & & & 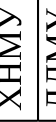 & $\frac{\lambda}{\delta}$ \\
\hline
\end{tabular}

\begin{tabular}{|c|c|c|c|c|c|c|c|c|c|c|c|c|c|}
\hline & 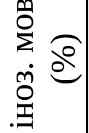 & $\begin{array}{l}0 \\
\dot{\sigma}\end{array}$ & 离 & $1 \mid \Delta_{0}^{+}$ & 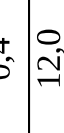 & 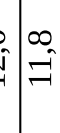 & $\stackrel{0}{\hat{m}}$ & 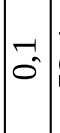 & \begin{tabular}{|l}
$\overrightarrow{1}$ \\
กิ
\end{tabular} & $\begin{array}{c}0 \\
\therefore \\
-1\end{array}$ & $\begin{array}{l}0 \\
\text { in }\end{array}$ & $\begin{array}{l}m \\
n \\
-1\end{array}$ & \\
\hline$\because$ & $\begin{array}{l}\stackrel{0}{0} \\
\sum_{\Sigma} \\
\dot{0} \\
\stackrel{\varrho}{\varrho}\end{array}$ & 1 & $\stackrel{n}{\sim}$ & $1 \mid \begin{array}{l}\mid l n \\
0\end{array}$ & $\begin{array}{lll}2 & 1\end{array}$ & 1 & $\hat{\sim}$ & $\begin{array}{l}\infty \\
\dot{f}^{f}\end{array}$ & $\begin{array}{l}m \\
\tilde{n}^{-}\end{array}$ & & $\begin{array}{l}0 \\
0 \\
-1\end{array}$ & $\begin{array}{l}\infty \\
\tilde{n}^{-}\end{array}$ & \\
\hline $\overrightarrow{\overrightarrow{0}}$ & 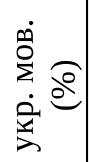 & $\begin{array}{l}0 \\
\hat{\sigma}\end{array}$ & $\vec{\infty}$ & $1 \overrightarrow{8}$ & $\begin{array}{l}-1 \\
\hat{n} \\
\infty \\
\infty\end{array}$ & $\begin{array}{l}\approx \\
\infty \\
\infty \\
\infty\end{array}$ & $\begin{array}{l}0 \\
\sigma^{-1}\end{array}$ & $\overrightarrow{\mathrm{R}^{0}}$ & $\begin{array}{l}m \\
\dot{m} \\
\dot{m}\end{array}$ & $\left|\begin{array}{c}0 \\
\hat{\otimes}^{-}\end{array}\right|$ & $\begin{array}{c}0 \\
\vdots \\
\infty \\
\infty\end{array}$ & $\begin{array}{l}0 \\
2 \\
2\end{array}$ & \\
\hline & 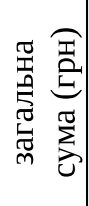 & $\begin{array}{l}8 \\
0 \\
8 \\
0 \\
10 \\
\sim \\
n\end{array}$ & $\begin{array}{l}8 \\
8 \\
8 \\
6 \\
10 \\
2 \\
0 \\
\infty\end{array}$ & 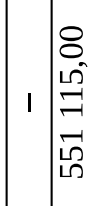 & 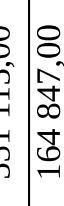 & 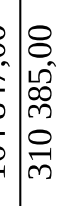 & 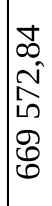 & $\mid \begin{array}{c}0 \\
10 \\
-1 \\
\hat{n} \\
8 \\
8 \\
10 \\
-1\end{array}$ & 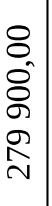 & 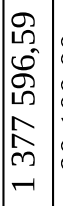 & $\begin{array}{l}8 \\
8 \\
8 \\
-1 \\
8 \\
8\end{array}$ & $\begin{array}{c}1 \\
0 \\
\infty \\
0 \\
\infty \\
8 \\
0 \\
0\end{array}$ & \\
\hline & 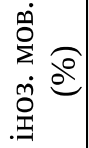 & $\begin{array}{l}\infty \\
\infty \\
\text { ma } \\
m\end{array}$ & $\begin{array}{l}0 \\
\infty 0^{\circ}\end{array}$ & $1 \mid \begin{array}{c}0 \\
\text { i }\end{array}$ & $\begin{array}{lll}\hat{j} & 0 \\
\end{array}$ & $\stackrel{\infty}{\wedge}$ & $\stackrel{0}{\stackrel{y}{y}}$ & $\mid \begin{array}{l}m \\
0\end{array}$ & 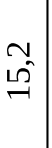 & $\begin{array}{l}0 \\
\sigma^{2}\end{array} \mid$ & $\begin{array}{l}0 \\
5^{n}\end{array}$ & $\begin{array}{l}m \\
n^{\prime}\end{array}$ & \\
\hline 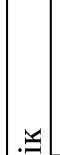 & $\begin{array}{l}\dot{0} \\
\sum_{\Sigma} \\
\dot{0} \\
\stackrel{\varrho}{\varrho}\end{array}$ & I & $\begin{array}{l}0 \\
\stackrel{0}{\rightarrow}\end{array}$ & $1 \mid \begin{array}{l}0 \\
\infty^{\circ}\end{array}$ & $\begin{array}{c}0 \\
0\end{array}$ & $=1$ & $\begin{array}{l}0 \\
00^{\circ} \\
e^{2}\end{array}$ & $\left|\begin{array}{l}n \\
\stackrel{n}{m}\end{array}\right|$ & 1 & 1 & $\begin{array}{l}0 \\
\infty^{\circ}\end{array}$ & $\begin{array}{l}\circ \\
\stackrel{0}{2}\end{array}$ & \\
\hline$\left|\begin{array}{l}0 \\
\stackrel{0}{\sim} \\
\mid\end{array}\right|$ & 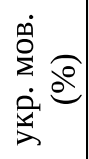 & \begin{tabular}{l}
2 \\
\multirow{0}{*}{}
\end{tabular} & $\begin{array}{l}0 \\
80\end{array}$ & $1 \mid \begin{array}{l}\circ \\
8\end{array}$ & : & hi & $\stackrel{0}{\stackrel{0}{0}}$ & $\left|\begin{array}{c}\tilde{1} \\
\tilde{\sigma}\end{array}\right|$ & $\begin{array}{l}\infty \\
\dot{\infty} \\
\dot{\infty}\end{array}$ & $\begin{array}{l}\overrightarrow{8} \\
\dot{8}\end{array}$ & $\begin{array}{c}\circ \\
\stackrel{\infty}{\infty}\end{array}$ & $\begin{array}{l}\infty \\
\dot{\mathrm{N}}\end{array}$ & \\
\hline & 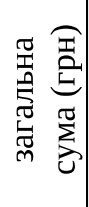 & $\mid \begin{array}{l}8 \\
0 \\
0 \\
\sigma \\
\hat{\sigma} \\
\hat{N}\end{array}$ & 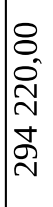 & 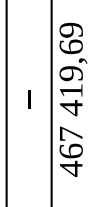 & 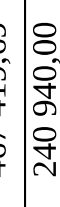 & 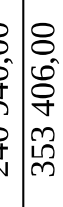 & $\begin{array}{l}8 \\
8 \\
8 \\
0 \\
10 \\
N\end{array}$ & 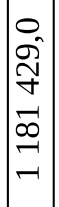 & $\begin{array}{l}10 \\
10 \\
10^{2} \\
10 \\
0 \\
0 \\
m \\
m\end{array}$ & 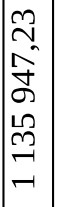 & 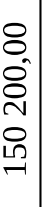 & 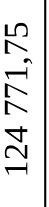 & \\
\hline $\mid$ & 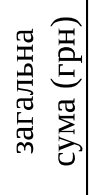 & 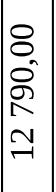 & 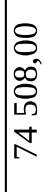 & $\mid \begin{array}{l}8 \\
8 \\
8 \\
8 \\
0 \\
\mathscr{7}\end{array}$ & 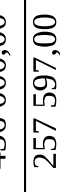 & 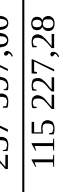 & 1 & $\begin{array}{c}8 \\
\mathbb{Z} \\
\hat{n} \\
\vec{N} \\
\mathbb{N} \\
\Sigma\end{array}$ & 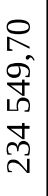 & \begin{tabular}{|l|}
$\overrightarrow{-}$ \\
$\hat{\tilde{D}}$ \\
0 \\
$\vec{\Delta}$ \\
$\vec{\sim}$ \\
-1 \\
-1
\end{tabular} & 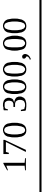 & 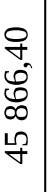 & $\begin{array}{l}8 \\
\dot{\mathbb{t}} \\
m \\
\infty \\
\infty\end{array}$ \\
\hline 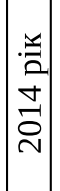 & 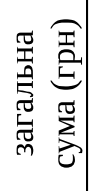 & 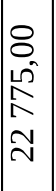 & 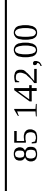 & 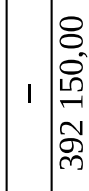 & 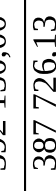 & 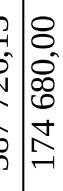 & 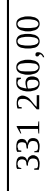 & $\begin{array}{l}8 \\
\tilde{\Xi} \\
\tilde{N} \\
\tilde{Z} \\
\tilde{N}\end{array}$ & 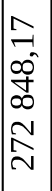 & 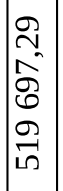 & $\begin{array}{l}8 \\
8 \\
8 \\
8 \\
n \\
+ \\
-1\end{array}$ & $\begin{array}{l}0 \\
0 \\
\infty \\
0 \\
\vdots \\
\vdots \\
0 \\
\llcorner\end{array}$ & \\
\hline 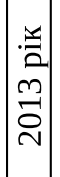 & 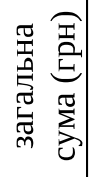 & 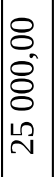 & 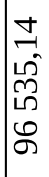 & 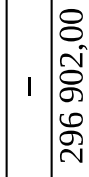 & 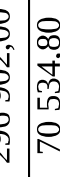 & $\begin{array}{l}8 \\
0 \\
\hat{f}\end{array}$ & 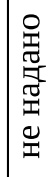 & 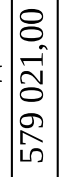 & 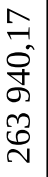 & 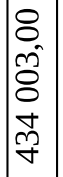 & $\begin{array}{l}8 \\
8 \\
8 \\
0 \\
8 \\
-1\end{array}$ & $\begin{array}{l}8 \\
\delta \\
\hat{\sigma} \\
\bar{\sigma} \\
\bar{\sigma}\end{array}$ & $\begin{array}{l}8 \\
0 \\
6 \\
5 \\
m \\
g \\
\text { v }\end{array}$ \\
\hline & $\begin{array}{l}\text { O } \\
\text { m}\end{array}$ & 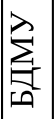 & 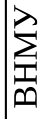 & $\sum_{i} \mid \frac{\lambda}{\sum_{n}}$ & $\sum_{\substack{i \\
\theta}}^{\vec{\lambda}}$ & 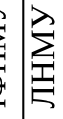 & 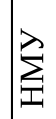 & 宣 & 齐 & 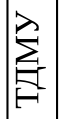 & త্త & $\sum_{\substack{x \\
\grave{x}}}^{\lambda}$ & $\sum_{i}^{\lambda}$ \\
\hline
\end{tabular}




\section{Матеріали XV Всеукраїнської науково-практичної конференції з міжнародною участю “АКТУАЛЬНІ ПИТАННЯ ВИЩОЇ МЕДИЧНОЇ ОСВІТИ В УКРАЇНІ”}

Таблиця 12. Придбана англомовна література у 2017 році

(кількість найменувань навчальних книг)

\begin{tabular}{|c|c|c|c|c|c|c|c|c|c|c|c|c|c|}
\hline $\begin{array}{l}\text { Назва дисципліни } \\
\text { (Крок 1: ЗЛП) }\end{array}$ & $\sum_{\substack{0 \\
0}}^{\lambda}$ & 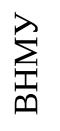 & 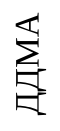 & 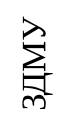 & $\sum_{\substack{\theta \\
\theta}}^{\lambda}$ & 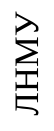 & 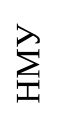 & $\sum_{\substack{I \\
0}}^{\lambda}$ & 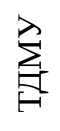 & 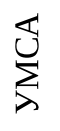 & $\sum_{\substack{x \\
\mid}}^{\lambda}$ & 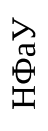 & $\begin{array}{c}\text { Кількість } \\
\text { ЗВО, які } \\
\text { придбали }\end{array}$ \\
\hline Біологія & & & & & & & 1 & & & & 1 & & 2 \\
\hline Норм. анатомія & & & 1 & 3 & & 2 & & & 2 & & 1 & & 5 \\
\hline Гістологія & & 1 & & 1 & 3 & & & & 1 & & & & 4 \\
\hline Норм. фізіологія & 1 & 1 & 1 & 3 & 1 & & & & 2 & 2 & & & 7 \\
\hline Біологічна хімія & 1 & 1 & 1 & 3 & 1 & 1 & 1 & & 1 & 1 & 1 & & 10 \\
\hline Патолог. фізіологія & 1 & 1 & 1 & 1 & 1 & & 1 & & 1 & 2 & & 1 & 9 \\
\hline \multicolumn{14}{|l|}{ Патолог. анатомія } \\
\hline Мікробіологія & 1 & & & 1 & & & & & & & & & 2 \\
\hline Фармакологія & & & & 4 & 1 & & 1 & & & & & & 3 \\
\hline $\begin{array}{l}\text { Придбано всього } 3 \\
\text { дисциплін “Крок 1”, }\end{array}$ & 4 & 4 & 4 & 16 & 7 & 3 & 4 & 0 & 7 & 5 & 3 & 1 & \\
\hline $\begin{array}{l}\text { Придбано всього } \\
\text { найменувань англо- } \\
\text { мовних книг } \\
\end{array}$ & 45 & 27 & 21 & 100 & 53 & 22 & 23 & 6 & 27 & 15 & 18 & 6 & \\
\hline
\end{tabular}

Таблиця 13. Англомовна література, видана в 2017 році

(кількість найменувань навчальних книг)

\begin{tabular}{|c|c|c|c|c|c|c|c|c|c|c|c|c|c|}
\hline $\begin{array}{c}\text { Назва дисципліни } \\
\text { (Крок 1) }\end{array}$ & $\sum_{\substack{-1 \\
\sum_{0}}}^{\lambda}$ & 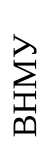 & $\sum_{\Sigma}^{\overleftarrow{E}}$ & $\sum_{m}^{\lambda}$ & 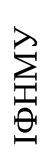 & $\sum_{\text {甹 }}^{\lambda}$ & $\sum_{1}^{\lambda}$ & $\sum_{0}^{\lambda}$ & $\sum_{-1}^{\lambda}$ & $\sum_{\lambda}^{\overleftarrow{S}}$ & $\sum_{\substack{x \\
\mid}}^{\lambda}$ & 尊 & $\begin{array}{c}\text { Кількість } \\
\text { ЗВО, які } \\
\text { видали англо- } \\
\text { мовні книги }\end{array}$ \\
\hline \multicolumn{14}{|l|}{ Біологія } \\
\hline Норм. анатомія & & & & & & & & & 1 & & & & 1 \\
\hline Гістологія & & & & & & 2 & 3 & & & 1 & 1 & & 4 \\
\hline \multicolumn{14}{|l|}{ Норм. фізіологія } \\
\hline Біологічна хімія & & & & 2 & & & & & & & & & 1 \\
\hline Патолог. фізіологія & & & & & & & & & & 2 & & & 1 \\
\hline \multicolumn{14}{|l|}{ Патолог. анатомія } \\
\hline Мікробіологія & 2 & & & 3 & & 1 & & & & & & & 3 \\
\hline Фармакологія & & & 1 & & & & & & & & & & 1 \\
\hline \multicolumn{14}{|l|}{ Аналітич. хімія } \\
\hline \multicolumn{14}{|l|}{ Органічна хімія } \\
\hline Фізична та кол. хімія & & & & 1 & & & & & & & & & 1 \\
\hline \multicolumn{14}{|l|}{$\begin{array}{l}\text { Фармацевтична бо- } \\
\text { таніка }\end{array}$} \\
\hline $\begin{array}{l}\text { Видано всього } 3 \\
\text { дисциплін “Крок 1” }\end{array}$ & 2 & 0 & 1 & 6 & 0 & 3 & 3 & 0 & 1 & 3 & 1 & 0 & \\
\hline $\begin{array}{l}\text { Видано всього } \\
\text { найменувань англо- } \\
\text { мовних книг }\end{array}$ & 19 & 4 & 12 & 52 & 9 & 12 & 12 & 6 & 9 & 11 & 11 & 4 & \\
\hline $\begin{array}{l}\text { Видано всього } \\
\text { англомовних мето- } \\
\text { дичних рекоменда- } \\
\text { цій (вказівок) }\end{array}$ & 0 & 5 & 0 & 3 & 18 & 14 & 4 & 0 & 10 & 0 & 28 & 0 & \\
\hline
\end{tabular}


Це наступні підручники та посібники:

1. Нормальна анатомія:

“Анатомія людини” (Б. Я. Ремінецький та інші), ТДМУ.

\section{2. Гістологія:}

“Цитологія, ембріологія та загальна гістологія” (Р. О. Білий та інші), ЛНМУ;

“Цитологія та загальна гістологія” м/п (Р. О. Білий), ЛНМУ;

“Гістологія, цитологія та ембріологія” (М. О. Мельник), НМУ;

"Гістологія, цитологія та ембріологія. Практикум” (М. О. Мельник, Ю. Чайковський), НМУ;

"Гістологія, цитологія та ембріологія. Словник" (М. О. Мельник, В. Лавриненко, Ю. Чайковський), HMY;

“Цитологія та загальна гістологія” (В. І. Щепітько та інші), УМСА;

"Гістологія, цитологія та ембріологія. Атлас" (О. Ю. Степаненко та інші), ХНМУ.

\section{3. Біологічна хімія:}

“Біологічна хімія” (К. В. Александрова та інші), ЗДМУ;

"Safety training features during biochemical investigations in chemical and biochemical laboratories" $\mathrm{H} / \Pi$ (К. В. Александрова та інші), ЗДМУ.

4. Патологічна фізіологія:

“Патофізіологія” (за ред. М. В. Кришталя), УМСA;

“Практикум з патофізіології” (В. О. Костенко та інші), УМСА.

5. Мікробіологія:

"Microbiology, Immunology and Virology.

Workbook” (О. О. Бліндер та інші), БДМУ;

"Microbiology, Immunology and Virology.Tutorials" (О. О. Бліндер та інші), БДМУ;

"Microbiological (culture) studies in the laboratory diagnosis of infectious diseases" (О. М. Камишний та інші), ЗДМУ;

"Microscopical (bacterioscopical) method ofresearch in the microbiological practice” (О.М.Камишний та інші), ЗДМУ;

"Glossary of microbiology, virology and immunology"

(О. М. Камишний та інші), ЗДМУ;

"Mcq in microbiology for the students of the specialist 222, 221, 220” (О. P. Korniychuk), ЛНМУ.

6. Фармакологія:

“Фармакологія. Робочий зошит” (В. І. Мамчур та інші), ДМА.

7. Фізична та колоїдна хімія:
“Фізична та колоїдна хімія” (М. О. Авраменко та інші), ЗДМУ.

Значна частина рукописів, підготовлених авторськими колективами ЗВО МОЗ України, запланована до видання у 2018 році (731, з них англомовних 110). Найбільше навчальної літератури заплановано видати у 2018 році: у Запорізькому державному медичному університеті (116), Національному медичному університеті імені О. О. Богомольця (100) та ДЗ “Луганський державний медичний університет” (66) (табл. 14).

У навчальному процесі всіх ЗВО МОЗ України активно використовуються електронні видання. Найбільша кількість електронних видань, які надійшли до фондів бібліотек ЗВО МОЗ України протягом 2013-2017 років (табл. 15): у Запорізькому державному медичному університеті (3256, у тому числі іноземною мовою 647), Харківському національному медичному університеті (828, у тому числі іноземною мовою 215) та ВДН3 України "Українська медична стоматологічна академія” (630, у тому числі іноземною мовою 181). При цьому найбільша кількість електронних видань, авторами яких є фахівці навчального закладу, як і минулого року: у Запорізькому державному медичному університеті (3086); Харківському національному медичному університеті (818) та ДВНЗ “Тернопільський державний медичний університет імені І. Я. Горбачевського MO3 України” (564). Найбільша кількість електронних видань, отриманих з вільних джерел, в Одеському національному медичному університеті (543).

Слід нагадати, що з метою удосконалення підготовки авторськими колективами у ЗВО електронних підручників та посібників були підготовлені методичні рекомендації “Підготовка електронних видань, дидактичних демонстраційних матеріалів, електронних навчальних посібників та підручників у вищих медичних навчальних закладах”, затверджені МОЗ України 17.09.2015 року та надіслані до ВНЗ МОЗ України для впровадження з листом від 18.09.2015 року № 23-01-9/443 [5], а також методичні рекомендації “Підготовка електронних навчальних матеріалів (електронних підручників та навчальних посібників) до видання”, розроблені фахівцями Національної медичної академії післядипломної освіти імені П. Л. Шупика спільно 3 МОЗ України та ЦМК (лист МОЗ України від 27.10.2015 року № 08.01-47/34048) [6]. 
Таблиця 14. Оперативний план видання навчальних книг (друкованих) для студентів ЗВО МОЗ України у 2018 році

\begin{tabular}{|c|c|c|c|c|}
\hline \multirow[t]{2}{*}{ Назва ЗВО } & \multicolumn{2}{|c|}{$\begin{array}{c}\text { План видання } \\
\text { (загальна кількість найменувань навч. книг) }\end{array}$} & \multicolumn{2}{|c|}{$\begin{array}{l}\text { Кількість запланованих } \\
\text { до видання підручників }\end{array}$} \\
\hline & всього & англ. мовою & загальна & з них за бюджетні кошти \\
\hline БДМУ & 54 & 4 & 2 & \\
\hline ВНМУ & 61 & 11 & 4 & 1 \\
\hline ДМА & 88 & 17 & 4 & 1 \\
\hline ЗДМУ & 116 & 14 & 3 & \\
\hline ІФНМУ & 20 & 4 & 4 & 1 \\
\hline ЛНМУ & 49 & 4 & 11 & 1 \\
\hline HMY & 100 & 22 & 24 & 3 \\
\hline НФаУ & 52 & 6 & 9 & \\
\hline OHMУ & 45 & 11 & 4 & 1 \\
\hline ТДМУ & 22 & 1 & 9 & \\
\hline УМСA & 44 & 8 & 3 & \\
\hline XНMУ & 14 & 4 & 7 & 4 \\
\hline ЛДМУ & 66 & 4 & & \\
\hline Всього & 731 & 110 & 84 & 12 \\
\hline
\end{tabular}

Таблиця 15. Кількість електронних видань, які надійшли до фондів бібліотек ВНЗ МОЗ України протягом 2013-2017 років (станом на 01.09.2017 року)

\begin{tabular}{|c|c|c|c|c|c|c|c|c|c|}
\hline \multirow{3}{*}{$\begin{array}{c}\text { ЗВО } \\
\text { МО3 } \\
\text { України }\end{array}$} & \multirow{3}{*}{\begin{tabular}{|c} 
Кількість \\
наймену- \\
вань \\
електронних \\
видань
\end{tabular}} & \multicolumn{8}{|c|}{3 них: } \\
\hline & & \multicolumn{2}{|c|}{$\begin{array}{c}\text { дозволами МОН, МОЗ } \\
\text { України, вчених рад ВНЗ } \\
\text { (з вересня } 2014 \text { року) }\end{array}$} & \multirow{2}{*}{$\begin{array}{c}\text { кількість } \\
\text { видань, } \\
\text { авторами } \\
\text { яких є } \\
\text { фахівці } \\
\text { даного ЗВО }\end{array}$} & \multirow{2}{*}{$\begin{array}{c}\text { кількість } \\
\text { видань, } \\
\text { які на- } \\
\text { дійшли } 3 \\
\text { дозволу } \\
\text { авторів }\end{array}$} & \multirow{2}{*}{$\begin{array}{c}\text { кількість } \\
\text { видань, } \\
\text { які отри- } \\
\text { мано } 3 \\
\text { вільних } \\
\text { джерел }\end{array}$} & \multirow{2}{*}{ укр. } & \multirow{2}{*}{ poc. } & \multirow{2}{*}{$\begin{array}{l}\text { іншими } \\
\text { мовами }\end{array}$} \\
\hline & & підручники & посібники & & & & & & \\
\hline БДМУ & 15 & & 2 & 15 & 15 & & 14 & & 1 \\
\hline ВНМУ & 105 & 104 & & & 104 & 1 & 104 & & 1 \\
\hline ДМА & 87 & 74 & 13 & 66 & 66 & 21 & 86 & 1 & \\
\hline ЗДМУ & 3256 & 32 & 401 & 3086 & 3256 & & 2334 & 275 & 647 \\
\hline ІФНМУ & 190 & 61 & 129 & 67 & 66 & 57 & 162 & 12 & 16 \\
\hline ЛНМУ & 13 & 1 & 3 & 4 & 3 & 10 & 4 & 0 & 9 \\
\hline HМУ & 21 & 19 & 2 & 1 & 21 & & 7 & 8 & 6 \\
\hline НФУ & 408 & 36 & 134 & 408 & 408 & & 247 & 97 & 64 \\
\hline OHМУ & 591 & 116 & 130 & 39 & 9 & 543 & 253 & 302 & 36 \\
\hline ТДМУ & 579 & & 579 & 564 & & 15 & 352 & 118 & 109 \\
\hline УМСA & 630 & 7 & 58 & 558 & 587 & 43 & 215 & 234 & 181 \\
\hline ХНМУ & 828 & 7 & 39 & 818 & 828 & & 270 & 343 & 215 \\
\hline ЛДМУ & & база & Ктронних & дань знахо & ся на ста & iiï розро & & & \\
\hline Всього & 6723 & 457 & 1490 & 5626 & 5363 & 690 & 4048 & 1390 & 1285 \\
\hline
\end{tabular}

Разом з тим необхідно враховувати, що відповідно до примітки 3 до пункту 6 додатка 14 Ліцензійних умов використання навчальних матеріалів лише в електронній формі - тільки для вибіркових дисциплін.

Висновки. Удосконалення організації підготовки студентів до складання іспиту з англійської мови за професійним спрямуванням як окремої компоненти ЄДКІ передбачає, зокрема:

1. Розробку заходів для забезпечення до 01.09.2019 року формування у студентів ЗВО МОЗ України, які не вивчають англійську мову як іноземну чи іноземну мову за професійним спрямуванням, компетентностей та результатів навчання, необхідних 
для складання іспиту з англійської мови за професійним спрямуванням як окремої компоненти ЄДКІ, у тому числі шляхом вивчення курсів за вибором “Іноземна мова (друга): англійська” та “Іноземна мова за професійним спрямуванням (друга): англійська”.

2. Опрацювання ряду роз'яснень щодо змісту завдань, зокрема при проведенні іспиту з англійської мови за професійним спрямуванням буде оцінюватись рівень професійної компетентності з англійської мови з урахуванням тем, які вивчав студент, опановуючи дисципліни “Англійська мова” та "Англійська мова (за професійним спрямуванням)”, чи будуть сформовані англійською мовою

\section{Список літератури}

1. Основи законодавства України про охорону здоров’я: Закон України, введений в дію Постановою Верховної Ради України від 19.11.1992 року № 2802-XII (із змінами і доповненнями).

2. Про вищу освіту : Закон України від 01.07.2014 року № 1556-VII (із змінами і доповненнями).

3. Про затвердження Ліцензійних умов провадження освітньої діяльності закладів освіти : Постанова Кабінету Міністрів України від 30.12.2015 року № 1187.

4. Мельник I. В. Забезпечення навчально-методичною літературою - вимога $з$ провадження освітньої діяльності у сфері вищої освіти відповідно до Ліцензійних умов провадження освітньої діяльності закладів освіти /

\section{References}

1. Zakon Ukrainy "Osnovy zakonodavstva Ukrainy pro okhoronu zdorovia”: postanova Verkhovnoi Rady Ukrainy vid 19.11.1992 № 2802 - XII (iz zminamy i dopovnenniamy) [Law of Ukraine "Fundamentals of Ukraine on Health Care” Resolution of Verkhovna Rada of Ukraine from November, 191992 No. 2802 - XII (as amended and supplemented)]. - Retrieved from: http://zakon3.rada.gov.ua/laws/ show/2801-12 [in Ukrainian].

2. Zakon Ukrainy "Pro vyshchu osvitu” vid 01.07.2014 № 15566-VII (iz zminamy) [Law of Ukraine “On higher education” from July, 01 2014, № 15566-VII (as amended)]. - Retrieved from: http://zakon.rada.gov/ua/go/1556-18 [in Ukrainian].

3. Litsenziini umovy provadzhennia osvitnioi diialnosti zakladiv osvity: postanova Kabinetu Ministriv Ukrainy vid 30.12.2015 № 1187 [Licensing options for conducting learning activity of education institutions: resolution of Cabinet of Ministers of Ukraine from December, 302015 субтести з 9 дисциплін, включених до змісту інтегрованого іспиту “Крок 1 ”.

3. Вжиття заходів для збільшення кількості навчально-методичної літератури, виданої англійською мовою, у бібліотеках ЗВО МОЗ України з урахуванням збільшення контингенту студентів, оскільки англомовну літературу з усіх дисциплін будуть використовувати у навчанні як іноземні студенти, так і вітчизняні.

4. Покращення матеріально-технічного оснащення кафедр іноземних мов для забезпечення запровадження у навчальний процес інноваційних технологій навчання, зокрема, аудіовізуальної, ситуативного моделювання та ін.; сучасне оснащення лінгафонних кабінетів.

I. В. Мельник, Т. І. Фаріон, М. О. Поліщук // Сучасні підходи до вищої медичної освіти в Україні : матеріали XIV Всеукр. наук.-практ. конф. $з$ міжнар. участю. Тернопіль : Укрмедкнига, 2017. - Т. 1. - С. 138-143.

5. Підготовка електронних видань, дидактичних демонстраційних матеріалів, електронних навчальних посібників та підручників у вищих медичних навчальних закладах : методичні рекомендації, затверджені МОЗ України 17.09.2015 року.

6. Підготовка електронних навчальних матеріалів (електронних підручників та навчальних посібників) до видання : методичні рекомендації (лист МОЗ України від 27.10.2015 року № 08.01-47/34048).

№ 1187]. - Retrieved from: http://zakon5.rada.gov.ua/laws/ show/1187-2015-п [in Ukrainian].

4. Melnyk, I.V., Farion, T.I., \& Polishchuk, M.O. (2017). Zabezpechennia navchalno-metodychnoiu literaturoiu - vymoha z provadzhennia osvitnioi diialnosti u sferi vyshchoi osvity vidpovidno do Litsenziinykh umov provadzhennia osvitnioi diialnosti zakladiv osvity [Courseware supply - requirements for conducting learning activity in higher education spheres in compliance with Licensing options for conducting learning activity of education institutions]. Suchasni pidkhody do vyshchoi medychnoi osvity $v$ Ukrainimodern approaches to higher medical education in Ukraine: Proceedings of the $14^{\text {th }}$ All-Ukrainian Scientific and Practical Conference with international participation. (pp.138-143). Ternopil: Ukrmedknyha [in Ukrainian].

5. Pidhotovka elektronnykh vydan, dydaktychnykh demonstratsiinyh materialiv, elektronnykh navchalnykh posibnykiv ta pidruchnykiv u vyshchykh medychnykh 
navchalnykh zakladakh: metodychni rekomendatsii, zatverdzheni MOZ Ukrainy 17.09.2015. [Preparation of electronic editions, didactive illustration materials, electronic textbooks and manuals in higher medical institutions: methodical recommendation as approved by the Ministry of Health of Ukraine from September, 17 2015]. [in Ukrainian].

Електронна адреса для листування: cmkvmo@ukr.net
6. Pidhotovka elektronnykh navchalnykh materialiv (elektronnykh pidruchnykiv ta navchalnykh posibnykiv) do vydannia: metodychni rekomendatsii. Lyst MOZ Ukrainy vid 27.10.2015 № 08.01-47/34048 [Redaction of electronic learning materials (electronic textbooks and manuals): methodical recommendation. Letter of the Ministry of Health of Ukraine from October, 272015 № 08.01-47/34048]. [in Ukrainian]. 